\title{
$\$$ Research Square

\section{Development of High-Performance Air Purifier using Human Hair and Vetiver (Chrysopogan Zizanioides) as Filter Media}

\section{Anand Kumar Varma.S}

EGS Pillay Engineering College

SUVALAKSHMI A ( $\square$ suvalakshmi17@gmail.com )

EGS Pillay Engineering College https://orcid.org/0000-0003-4228-6396

\section{MANJULAK R}

SASTRA University School of Computing: Shanmugha Arts Science Technology and Research Academy School of Computing

\section{Research Article}

Keywords: Air pollution, Particulate Matter (PM), Total volatile organic compounds (VOC), Air Purifier, Human Hair, Vetiver

Posted Date: June 2nd, 2021

DOI: https://doi.org/10.21203/rs.3.rs-573244/v1

License: (c) (1) This work is licensed under a Creative Commons Attribution 4.0 International License. Read Full License 


\title{
Development of High-Performance Air Purifier using Human Hair and Vetiver (Chrysopogan Zizanioides) as Filter Media
}

\author{
Anand Kumar Varma.S ${ }^{1}$, Suvalakshmi. $\mathrm{A}^{2^{*}}$,Manjula.K.R ${ }^{3}$ \\ ${ }_{1 \& 2}$ Department of Civil Engineering, E. G.S Pillay Engineering College, Nagapattinam-609107,India \\ 3 Department of CSE, School of Computing, SASTRA University, Thanjavur-613401, Tamil Nadu,India \\ ${ }^{I}$ Authoremail:manjussakv@yahoo.co.in \\ ${ }^{2 *}$ Corresponding Author email:suvalakshmi17@gmail.com \\ ${ }_{3}^{3}$ Author email:smanjuanand@gmail.com
}

\begin{abstract}
Purpose-The global crisis of extreme air pollution is encountered nowadays due to the burning of fossil fuel, vehicular emission, modern sophistication and industrialization. These result infusions of high levels of Smoke, Particulate Matter (PM), Total volatile organic compounds $(\mathrm{VOC})$, Hydrocarbons $(\mathrm{HCHO})$, Nitrogen Oxides $\left(\mathrm{NO}_{\mathrm{x}}\right)$, Sulfur Oxides $\left(\mathrm{SO}_{\mathrm{x}}\right)$, Carbon Monoxide $(\mathrm{CO})$ and other air pollutants into the atmosphere.
\end{abstract}

Findings- Therefore, the development of a cost-saving air purifier is extremely essential with naturally occurring resources that are readily available throughout all the places at some point in time.A compact, flexible, modular and low-cost air purifier has designed employing a combination of porous plug and two filter media developed from natural resources.

Methodology-The air purification unit is horizontal shaped and made with a simple PVC pipe. The first filter media was developed by mixing human hair with low-cost vegetable Mahua oil and the second one by wetting Vetiver (Chrysopogan zizanioides) with water. A mixture of human hair with Mahua oil can absorb the suspended particulate matter of size above 2.5 $\mu \mathrm{m}$, and wet Vetiver shows the enormous capability of absorption of gases like NOx, SOx and Hydrocarbons and adsorption of particle size even less than $2.5 \mu \mathrm{m}$ like PM1. Moreover, due to the pleasant smell, wet Vetiver can produce fresh air.

Value-The cleaning and disposals of such naturally derived products are easy because of complete biodegradability and no negative impact on the environment. To restrict the filter media movement, porous plugs are coupled at the inlets and outlets of pipeline and filters. Due to the Joule-Thomson effect, the air coming out of the porous plug becomes $50^{\circ} \mathrm{C}$ cooler than the input air. The pollutant removal efficiency of indoor was found to be more than $60 \%$ were in the outdoor residential areas, it was more than $75 \%$, and in the heavily crowded regions, it evaluated to be more than $65 \%$. Amidst the alarming air pollution scenario throughout the world, such an invented device should be welcome due to the excellent performance as reflected in the production of pollutant-free fresh air at reduced temperature.

Keywords:Air pollution,Particulate Matter (PM), Total volatile organic compounds (VOC), Air Purifier, Human Hair, Vetiver.

\section{INTRODUCTION}

\subsection{AIR POLLUTION}

InIndia air pollution is a severe issue, with the primary sources being fuel adulteration, vehicular emission and traffic congestion(A.B. Ozturk,el al.2011)(Akarsh Verma, V.K. el al. 2016). The burning of fossil fuels releases high levels of Smoke, Particulate Matter (PM), Total volatile organic compounds (VOC), Hydrocarbons (HCHO), Nitrogen Oxides (NOx), Sulfur Oxides (SOx), Carbon Monoxide (CO) and other air pollutants into the atmosphere(Angus Shiue, elal. 2019). Therefore, with worsening air quality, it is essential that we have to be aware of the quality of air that we breathing(Annie Melinda Paz-Alberto, elal.2013). Exposure to particulate matter for a long time can lead to respiratory and cardiovascular diseases(M. Sharma,. el al2003). Everyyear over a million Indians die prematurely due to particle pollution(D. Balasankar, el al.2013). Therefore, it becomes necessary to purify the air in public areas where the pollution levels are exceeding the prescribed standards(Fortoul, T.I. el al., 2011). 


\begin{tabular}{|c|c|c|c|}
\hline Sl.No. & Author's & $\begin{array}{l}\text { Findings } \\
\end{array}$ & Interpretation \\
\hline 1. & $\begin{array}{l}\text { Aditya Roy el } \\
\text { al.(2019) }\end{array}$ & $\begin{array}{l}\text { The various conventional and effective } \\
\text { methods to filter PM } 2.5 \text { by using } \\
\text { Activated carbon,Transparent PAN } \\
\text { filter,s Photocatalytic materials and } \\
\text { Soy proteins and silk nanofibrils. }\end{array}$ & $\begin{array}{l}\text { The various general and modern methods } \\
\text { of air purification were studied and } \\
\text { reviewed. And also noted that from future } \\
\text { scope combination will be a enconomical } \\
\text { solutions. }\end{array}$ \\
\hline 2. & $\begin{array}{l}\text { Akarsh Verma } \\
\text { el al.(2016) }\end{array}$ & $\begin{array}{l}\text { The humar hairs mechanical } \\
\text { properties,chemical experiment of } \\
\text { human hair fiber,thermal analysis anf } \\
\text { ecological importance are reviewed. }\end{array}$ & $\begin{array}{l}\text { The study of different characteristics of } \\
\text { human hair and its application employed } \\
\text { and also hair regains its original position } \\
\text { after removal of the deformed load. }\end{array}$ \\
\hline 3. & $\begin{array}{l}\text { Negisa Darajeh } \\
\text { el al.(2014) }\end{array}$ & $\begin{array}{l}\text { To demonstrate the potential of Vetiver } \\
\text { grass in reducing the biological oxygen } \\
\text { demand (BOD) and chemical oxygen } \\
\text { demand (COD) and investigate } \\
\text { biomass production. }\end{array}$ & $\begin{array}{l}\text { The detailed study of vetiver wastewater } \\
\text { treatment system and different } \\
\text { characteristics of vetiver grass. }\end{array}$ \\
\hline 4. & $\begin{array}{l}\text { Emily Cheek el } \\
\text { al.(2020) }\end{array}$ & $\begin{array}{l}\text { To observe the effect of portable air } \\
\text { purifiers (PAPs) on indoor air quality } \\
\left(\mathrm{PM}_{2.5}\right) \text { of between } 22.6 \text { and } 92.0 \% \\
\text { with the use of PAPs when compared } \\
\text { to the control. }\end{array}$ & $\begin{array}{l}\text { A detailed study on how the PAP results in } \\
\text { short-term reductions in } \mathrm{PM}_{2.5} \text { in the } \\
\text { indoor environment. }\end{array}$ \\
\hline 5. & $\begin{array}{l}\text { Julie F. Hart el } \\
\text { al. (2011) }\end{array}$ & $\begin{array}{l}\text { To evaluate the value of a portable air } \\
\text { purifier in decreasing particle } \\
\text { concentrations accompanying with } \\
\text { wood combustion. }\end{array}$ & $\begin{array}{l}\text { the effectiveness of an electrostatic filter } \\
\text { portable air purifier was studied. }\end{array}$ \\
\hline 6. & $\begin{array}{l}\text { C Pedroletti et } \\
\text { al. (2009) }\end{array}$ & $\begin{array}{l}\text { To examine the Exposure to breathe in } \\
\text { allergens is a pathogenetic feature in } \\
\text { allergic asthma. But, most studies that } \\
\text { earlier looked at air cleaning devices } \\
\text { have shown little or no effect on } \\
\text { patients with perennial allergic asthma. }\end{array}$ & $\begin{array}{l}\text { The detailed study of the clean air during } \\
\text { sleep with the influenced factor }\end{array}$ \\
\hline 7. & $\begin{array}{c}\text { V.P. } \\
\text { Singh(2017) }\end{array}$ & $\begin{array}{l}\text { To overcome these toxic waste } \\
\text { atmosphere } \\
\text { situations the concept of using plants } \\
\text { for remediation of water, soil and air } \\
\text { pollution. }\end{array}$ & $\begin{array}{l}\text { A detailed study on Phytoremediation as } \\
\text { acleaning tool for pollutants. }\end{array}$ \\
\hline 8. & $\begin{array}{l}\text { Vannan Kandi } \\
\text { Vijayan el al. } \\
(2015)\end{array}$ & $\begin{array}{l}\text { This journal discussesing the effect of } \\
\text { air pollutants with special focus on } \\
\text { indoor air pollutants and the benefits of } \\
\text { air filters in improving indoor air } \\
\text { quality. }\end{array}$ & $\begin{array}{l}\text { The detailed study on indoor and outdoor } \\
\text { air pollutant with its contamination. }\end{array}$ \\
\hline 9. & $\begin{array}{l}\text { N Yamamoto et } \\
\text { al. (2010) }\end{array}$ & $\begin{array}{l}\text { To report approximately } 500 \text { indoor- } \\
\text { outdoor air exchange rate (AER) } \\
\text { calculations based on measurements } \\
\text { conducted in residences in three US } \\
\text { metropolitan areas in 1999-2001 }\end{array}$ & $\begin{array}{l}\text { Studied various quantitative and } \\
\text { qualitative data to characterize residential } \\
\text { AERs in three US urban areas with } \\
\text { different climate attributes }\end{array}$ \\
\hline 10. & $\begin{array}{l}\text { Zhe Wang et } \\
\text { al.(2016) }\end{array}$ & $\begin{array}{l}\text { To introducing Hybrid poly(lactic } \\
\left.\text { acid)/titania (PLA/ } / \mathrm{TiO}_{2}\right) \text { fibrous } \\
\text { membranes exhibiting excellent air } \\
\text { filtration performance and good } \\
\text { antibacterial activity were prepared via } \\
\text { the electrospinning technique. }\end{array}$ & $\begin{array}{l}\text { Studied the result of prepared } \\
\mathrm{PLA} / \mathrm{TiO}_{2} \text { fibrous membrane loaded with } \\
1.75 \mathrm{wt}^{2} \mathrm{TiO}_{2} \text { nanoparticles formed at a } \\
\text { relative humidity of } 45 \% \text { exhibited a high } \\
\text { filtration efficiency }(99.996 \%) \text { and a } \\
\text { relatively low pressure drop }(128.7 \mathrm{~Pa}) \text {, as } \\
\text { well as a high antibacterial activity of } \\
99.5 \% \text {. }\end{array}$ \\
\hline
\end{tabular}


Research gap:This research is a newinnovative idea of development of high-performance air purifier using human hair and vetiver (chrysopogan zizanioides) as filter media.

\subsection{SCOPE OF WORK}

The opportunity of the contemporary effort is to develop an air purifier in research laboratory measure by introducing a model can reduce the air pollution as per the world health organisation permited level by using a naturally accuring human hair and vetiver as a filter media. To reduce the air pollution causing due to the emission from various vehicles and burning of fossil fuel. In order to protect our environment to provide a clean air .

\subsection{OBJECTIVES}

1. To design and develop a compact, flexible, modular and low-cost air purifier employing a combination of porous plug and two filter media from natural resources.

2. To reduce the infusions of high levels of Smoke, Particulate Matter (PM), Total volatile organic compounds (VOC), Hydrocarbons ( $\mathrm{HCHO})$, Nitrogen Oxides $\left(\mathrm{NO}_{\mathrm{X}}\right)$, Sulfur Oxides $\left(\mathrm{SO}_{\mathrm{X}}\right)$, Carbon Monoxide $(\mathrm{CO})$ and other air pollutants from the atmosphere.

\section{METHODOLOGY}

The invented air purifier model was developed based on PVC Pipes and fittings, including the 3 stage filtration process using a porous plate, hair media and Vetiver media(P.Thilagaraj,. el al.,2014). To keep the Vetiver wet, channels for water inlet and outlet were also incorporated(V.P.Singh and Pawan Kumar 2017). The inlet air forced to enter the purifier unit using a blower at the inlet section with an air discharge rate of $0.5345 \mathrm{~m}^{3} / \mathrm{s}$ (Rojas-Sandoval $\mathrm{J}, 2020$ ). At the interior, air comes first in contact with a porous plug which separates the large-sized impurities, dust and particulate matters(Adams, R. P. el al., 1998). Double layered porous plug screens of pore size $3 \mu \mathrm{m}$ were used, which helps in the reduction of outlet air temperature(Mickovski, S. el al., 2005). According to the Joule Thompson effect, air passing from higher concentration to lower concentration tend the air to work itself, and the particles of air are colliding with each other while scattering through pores, then the temperature of the air is considerably reduced(Vannan Kandi Vijayan el al., 2015). If in case the temperature of the air is high, then the capture or settlement of air pollutants is difficult. So, reduction of air temperature is aimed to yield high removal of suspended particles(Zhe Wang., el al. 2016). The porous plates coupled in 5 places:

- One at Inlet Pipe (Pore size is $3 \mu \mathrm{m}$ because of Double-layer to increase efficiency)

- One at entry and one at the exit of the first and second filter media (Pore size of $10-15 \mu \mathrm{m}$ )

In the next stage, human hair mixed with vegetable oil adsorbs Particulate Matter (PM10)(Van Boven F.E., el al., 2020). This idea was developed by observing the biological system of the human nose where human hairs wetted with mucus fromthe nose prevents the entry of dust and other particulate matters during inhalation of air(Aditya Roy el al. 2018). This principle is exceptionally essential in removing or capturing the suspended particles and other atmospheric pollutants of particle size more than $2.5 \mu \mathrm{m}$ (example, $\mathrm{PM}_{2.5}$ and $\mathrm{PM}_{10}$ )(Review on air purifier Gowri Rajapandian el al. 2019). Human hair of size $50-100 \mu \mathrm{m}$ and upto the length of $2 \mathrm{~cm}$ were used and mixed with Mahua oil, which could trap the suspended particles of size above $2.5 \mu \mathrm{m}$ (Julie F. HartHindawi el al. 2011). Though any kind of vegetable oil with high viscosity can serve this purpose but, the cost of Mahua oil is low, and a very less volume of about $30 \mathrm{ml}$ required for a complete cycle till getting blockedcompletely with pollutants(Yun Han Wang el al. 2015). Thus, the use of it abates pollution of the environment, and the proposal turns more cost-saving and environmentally concerned(EmilyCheek el al. 2021). These media kept covered with porous screens on both sides to restrict the movement of hair towards the outlet. If the pollution level is very high, then the hair filter media will get highly clogged, and replacement of media is required(Ashton Lim Suelee el al. 2017). Moreover, disposal is easy enough to be done in a pit because vegetable oil and human hair are completely naturally bio-degradable( Chomchalow, N. 2003).

The remaining PM2.5 is absorbed by water wet vetiver media with subsequent absorption of SOx, NOx and hydrocarbons(Danh, L. T., el al. 2009). Vetiver (Chrysopogan Zizanioides), locally known as khus-khus, is a native to Asia and mainly grows like a weed, possess the property of absorbing essential (nutrients) and non-essential (even pollutants) particles when they are wet because water is the primary requirement for Vetiver(Darajeh, Nel al.., 2014). Wetted Vetiver keeps enormous capability of absorbing gaseous particles like $\mathrm{NO}_{\mathrm{x}}, \mathrm{SO}_{\mathrm{x}}$, and $\mathrm{HC}$ with the efficient ability of absorption and adsorption of particle size even less than $2.5 \mu \mathrm{m}$ like $\mathrm{PM}_{1}$ (James L. Sublett2011). 
Producing a delightful smell, turns the environment fresher than the synthetic filters(Green R et al., 1999). A bunch of Vetiver of size $0.6-1.5 \mathrm{~mm}$ were used as the secondary filter media protected with the porous screens on either side(Hanssen,2004). By periodical wetting through the entry pipe of water, the Vetiver filter was kept wet three holes of $1 \mathrm{~cm}$ diameter made to the water inlet on the top of the Vetiver filter(Macintosh D.L. et al., 2008). Entry of air restricted by the use of valves(Johnson L., et al. 2009). Cleaning of Vetiver media could be quickly done by cleaning and backwashing. Because of being a natural product, it is entirely bio-degradable and has no negative impacts on the environment(Fisk WJ et al. 2002). Porous plug screens also integrated to prevent the movement of Vetiver filter media, which also plays an influential role in reducing the temperature at each level(Sublett J.L., et al. 107 2010).

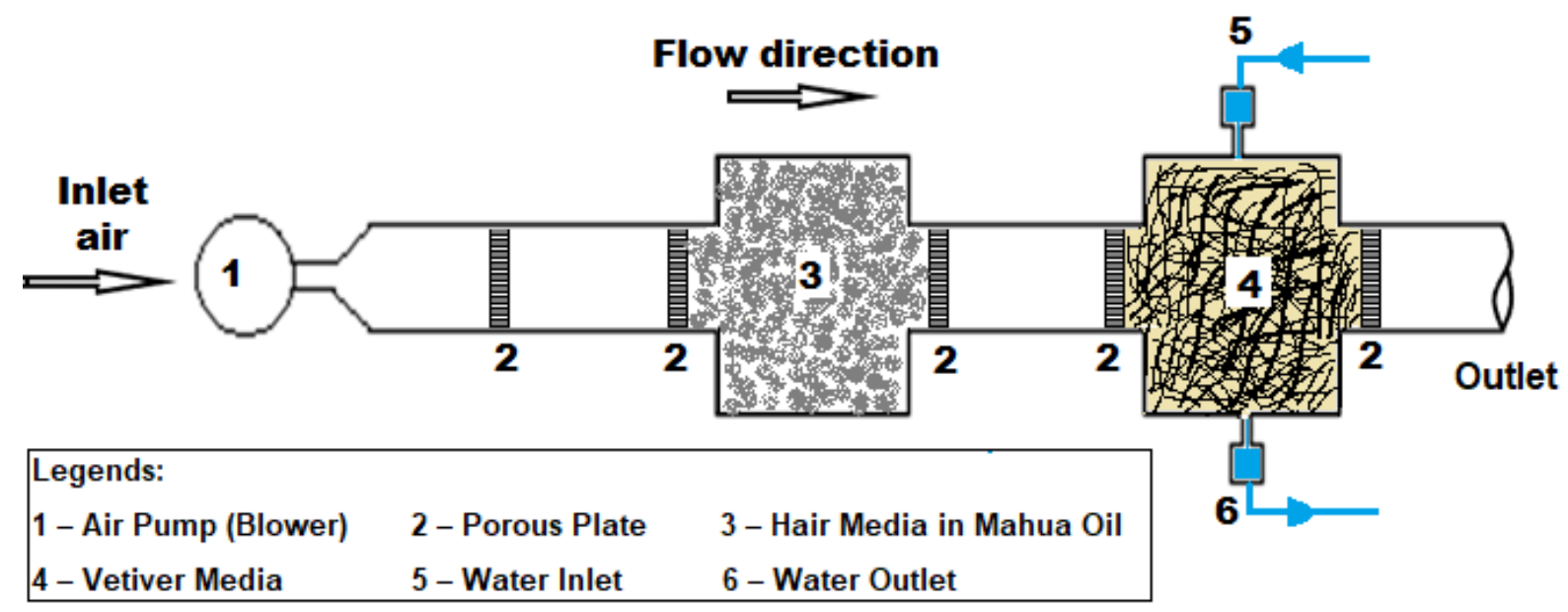


(a)

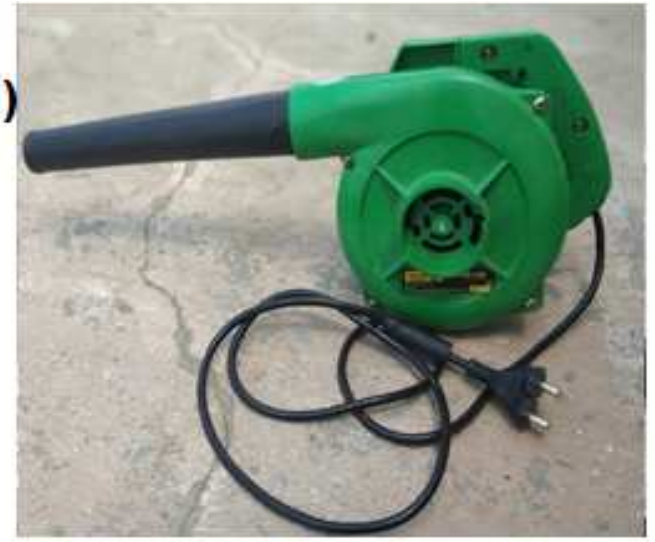

(c)

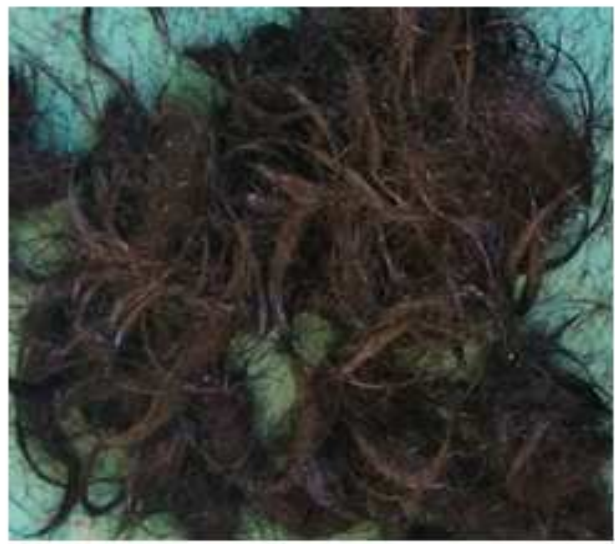

(b)

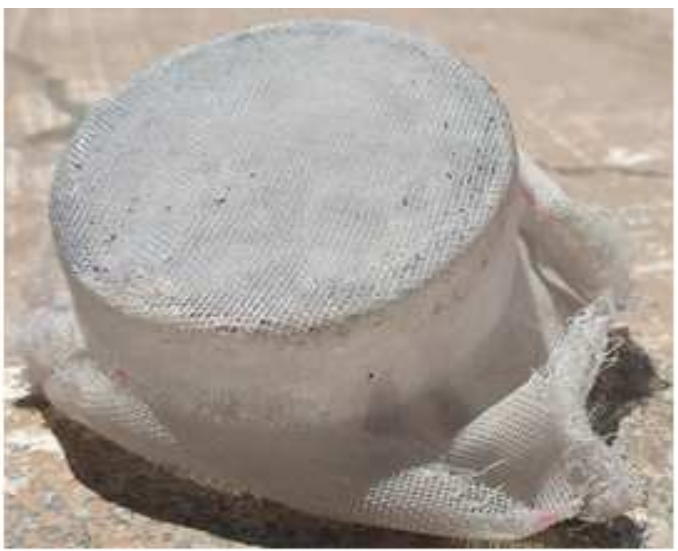

(d)

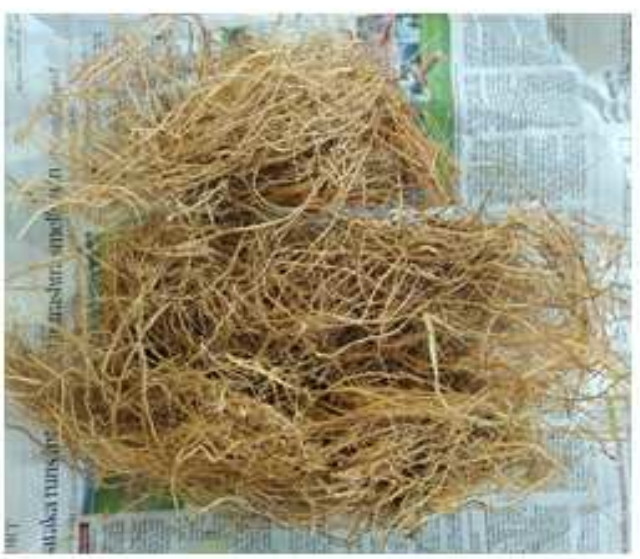

Figure 2. Essential components of the air purifier:

(a) air blower, (b) porous plug, (c) human hair and (d) vetiver.

\subsection{OVERALL WORKING PROCEDURE OF AIR PURIFIER}

Step. 1. Before running the air purifier, it is laid horizontally, and joints of both the filter media are required to be verified. Vetiver is wetted with water by inlet water pipes, and excess water is recycled.

Step. 3. The air stream is initially passed through the first porous plug (Double layer Screen), where theair temperature gets slightly reduced, and some large-sized pollutants get trapped.

Step. 4. Next, the air jet is passing through the primary filter media (Hair mixed with Mahua oil), where the particles of size above $2.5 \mu \mathrm{m}$ get captured.

Step. 5. Subsequently, the air is passed through the secondary membrane (Vetiver wetted with water). It absorbs and adsorbs the SPM of size less than $2.5 \mu \mathrm{m}$. It also captures $\mathrm{NO}_{\mathrm{x}}, \mathrm{SO}_{\mathrm{x}}, \mathrm{HC}$ and other organic compounds. Step. 6. After the cleaning and backwashing, Vetiver becomes reusable.

\subsection{PERFORMANCE ANALYSIS}

The level of pollution increases with an increase in the temperature. Thus, from morning to noon, the pollution level slightly increases(Stillerman A. et al. 2010). During the afternoon, high temperature remains along with high traffic and vehicles, which consequently elevates pollution. Now, for the air purifier unit, removal efficiency is calculated as:

Pollutant Removal Efficiency $=\frac{\text { Initial Pollution Level-Final Pollution Level }}{\text { Initial Pollution Level }}$ X 100\% 
In fact, the pollutant removal efficiency exhibited by the air purifier unit for indoor observed to be more than $60 \%$ for $\mathrm{PM}_{1}, \mathrm{PM}_{2.5}$ and $\mathrm{PM}_{10}$ (Pedroletti $\mathrm{C}$ et al. 2009).Particulate matter removal efficiency in the outdoor residential area found to be more than $75 \%$, and for a heavily crowded region like bus-stand was found to be more than $65 \%$ (Morris RJ et al. 2006). Due to the Joule-Thomson effect, it observed that the temperature of exit air was about $5^{0} \mathrm{C}$ lesser than the incoming air(Hacker DW, et al., 2005).

\subsection{COMPLETE SPECIFICATION}

The accompanying drawings, which are included in and form a part of the specification, illustrate an incarnation of the present invention and, together with the description, serve to explain the principles of the invention(Sulser $\mathrm{C}$ et al. 2009). In the drawings:

\section{Air blower}

2. Hair Media (Human hair mixed with Mahua oil)

3. Vetiver media (Vetiver wetted with water)

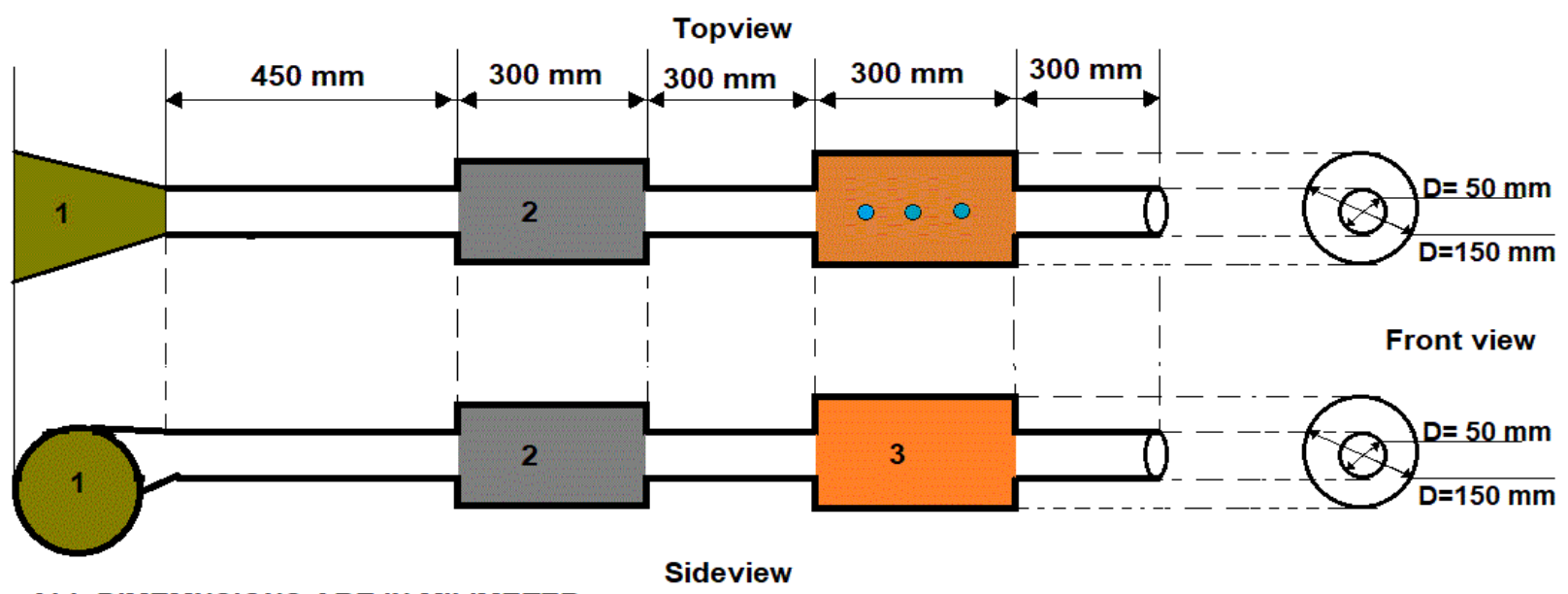

ALL DIMEMNSIONS ARE IN MILIMETER

Figure 3. Diagram with dimensions of the invention.

The proto-model of the Purifier developed is of the following specifications in Table 1.

Table 1. Specifications of High-Performance Air Purifier

\begin{tabular}{|c|c|c|c|}
\hline S. No & Machine Parts & Purpose & Specifications \\
\hline 1 & $\begin{array}{c}\text { Air Pump } \\
\text { (Blower) }\end{array}$ & $\begin{array}{l}\text { The pump can be of any type that } \\
\text { should suck enough air from the } \\
\text { atmosphere and release it at one point. }\end{array}$ & $\begin{array}{l}\text { Diameter of fan in blower }=10 \mathrm{~cm} \\
\text { Speed }=13000 \mathrm{rpm} \\
\text { Frequency }=50 \mathrm{~Hz} \\
\text { Power }=230 \mathrm{~V}, 350 \mathrm{~W} \mathrm{AC}\end{array}$ \\
\hline
\end{tabular}




\begin{tabular}{|c|c|c|c|}
\hline & & & $\begin{array}{l}\text { Linear Velocity }=68.06 \mathrm{~m} / \mathrm{s} \\
\text { Air Discharge }=0.5345 \mathrm{~m}^{3} / \mathrm{s}\end{array}$ \\
\hline 2 & Pipeline & $\begin{array}{l}\text { PVC pipeline employed for the } \\
\text { transportation of air from an air blower } \\
\text { to an outlet. }\end{array}$ & $\begin{array}{l}\text { Diameter }=50 \mathrm{~mm} \\
\text { Upto hair media chamber, length of pipe: } \\
450 \mathrm{~mm} \\
\text { From hair media chamber to vetiver } \\
\text { media chamber, length of pipe: } 300 \mathrm{~mm} \\
\text { From vetiver media chamber to outlet, } \\
\text { length of pipe: } 300 \mathrm{~mm}\end{array}$ \\
\hline 2 & Porous Plate & $\begin{array}{l}\text { The screens of pore size } 3 \mu \mathrm{m} \text { (Double- } \\
\text { layered screen), used as the porous } \\
\text { plate. The porous plates are used in } 5 \\
\text { places }\end{array}$ & $\begin{array}{l}\text { - Inlet Pipe Pore size is } 3 \mu \mathrm{m} \text { because } \\
\text { of (Double-layer to increase } \\
\text { efficiency) } \\
\text { - Entry and exit of both membranes } \\
\text { (Pore size of } 10-15 \mu \mathrm{m} \text { ) }\end{array}$ \\
\hline 3 & $\begin{array}{l}\text { Hair media } \\
\text { chamber }\end{array}$ & $\begin{array}{l}\text { The thick hair in the nostrils can } \\
\text { prevent the entry of PM10, in the same } \\
\text { way, Hair media made viscous using } \\
\text { Mahua oil. } \\
\text { It can trap the PM of size above } 2.5 \\
\mu \mathrm{m} \text {. These media are provided with } \\
\text { screen membranes on both sides to } \\
\text { prevent the movement of media. }\end{array}$ & $\begin{array}{l}\text { Hair media chamber dimensions: } 150 \\
\text { mm diameter and length } 300 \mathrm{~mm} \\
\text { Hair size } 50-100 \mu \mathrm{m} \text { and upto the length } \\
\text { of } 2 \mathrm{~cm} \text { and mixed them with the mahua } \\
\text { oil. }\end{array}$ \\
\hline 4 & Vetiver Media & $\begin{array}{l}\text { Vetiver is used in many fields to } \\
\text { reduce the pollution from water and } \\
\text { soil. In this innovative work, the } \\
\text { Vetiver is used to reduce pollution } \\
\text { from the air. } \\
\text { The Vetiver having the property of } \\
\text { absorbing essential (nutrients) and } \\
\text { non-essential (even pollutants) } \\
\text { particles when they are wet because } \\
\text { water is the primary requirement for } \\
\text { Vetiver. Wetted Vetiver having the } \\
\text { property of absorbing gaseous } \\
\text { pollutants like NOx, SOx, and HC. It } \\
\text { will also absorb and adsorb the } \\
\text { particles of size, even less than } 2.5 \mu \mathrm{m} \\
\text { (example, PM1). It has a very pleasant } \\
\text { smell that makes the environment } \\
\text { better many times than synthetic }\end{array}$ & $\begin{array}{l}\text { Vetiver media chamber dimensions: } 150 \\
\text { mm diameter and length } 300 \mathrm{~mm} \\
\text { A bunch of Vetiver of size } 0.6-1.5 \mathrm{~mm} \\
\text { dia and } 120-150 \mathrm{~mm} \text { in length are used } \\
\text { as the secondary filter media. }\end{array}$ \\
\hline
\end{tabular}




\begin{tabular}{|c|l|l|l|}
\hline & filters. & \\
\hline 5 & $\begin{array}{c}\text { Water Inlet and } \\
\text { outlet }\end{array}$ & $\begin{array}{l}\text { Continuous wetting of Vetiver could } \\
\text { done through the water inlet. Hence, } \\
\text { the inlet and outlet pipes provided for } \\
\text { the entry and exit of water.Three holes } \\
\text { of 1cm diameter are made for the } \\
\text { water inlet on the top of the Vetiver } \\
\text { media chamber. }\end{array}$ & Length- $1000 \mathrm{~mm}$ \\
\hline 6 & Water Outlet & $\begin{array}{l}\text { It was used to remove the excess water } 10 \mathrm{~mm} \\
\text { and also used to wash the Vetiver } \\
\text { media. }\end{array}$ & Length- $1000 \mathrm{~mm}$ \\
\hline
\end{tabular}

\section{EXPERIMENTATION}

\subsection{MEASUREMENT OF POLLUTION}

Initially, the pollution level is measured by Air Quality Indicator at four places of Karur(Bernstein JA et al. 2005).

155 They are,

The readings taken from $6 \mathrm{AM}$ to $11 \mathrm{PM}$. During the measurement, the temperature varies as per the forecasted temperature(Batterman S, 2005).

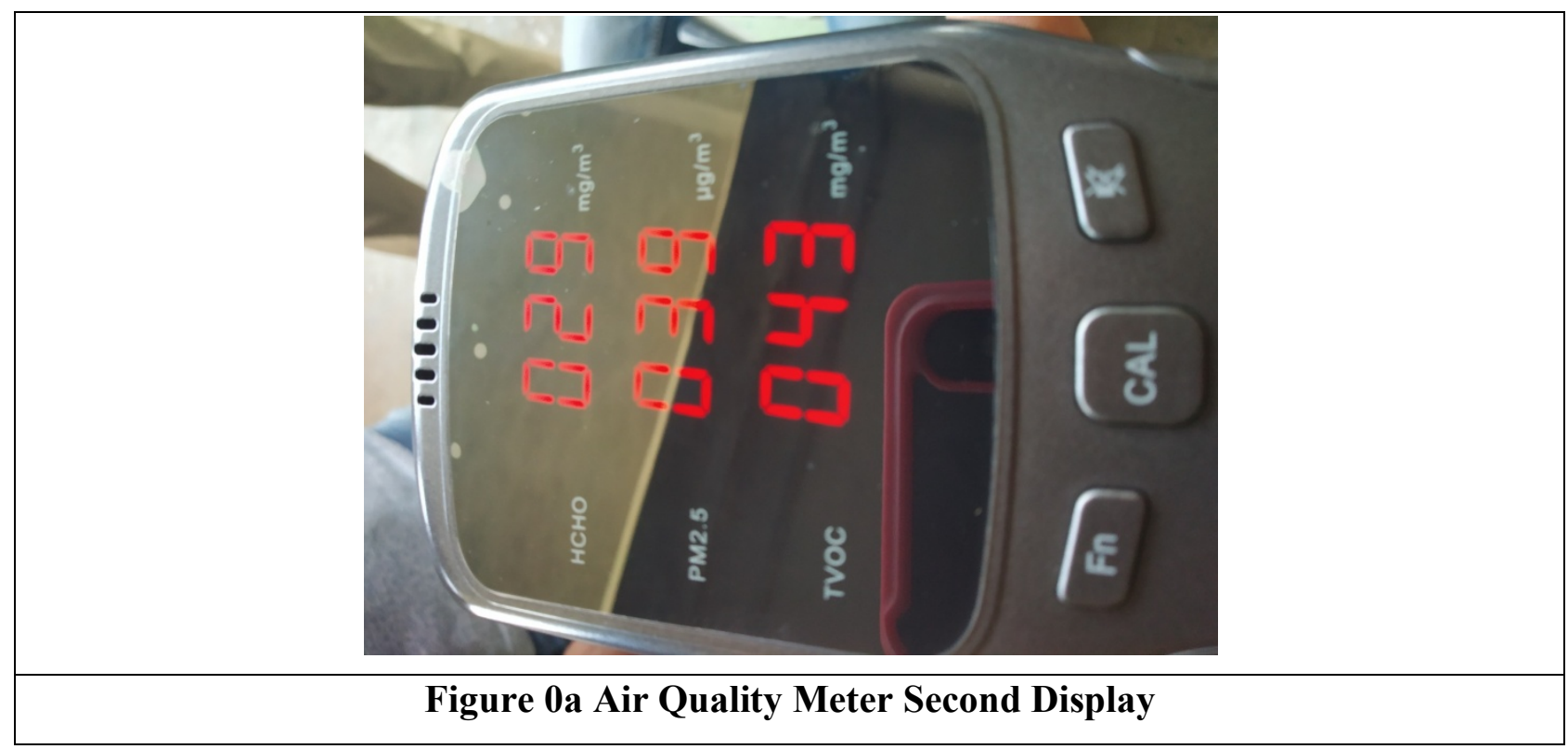




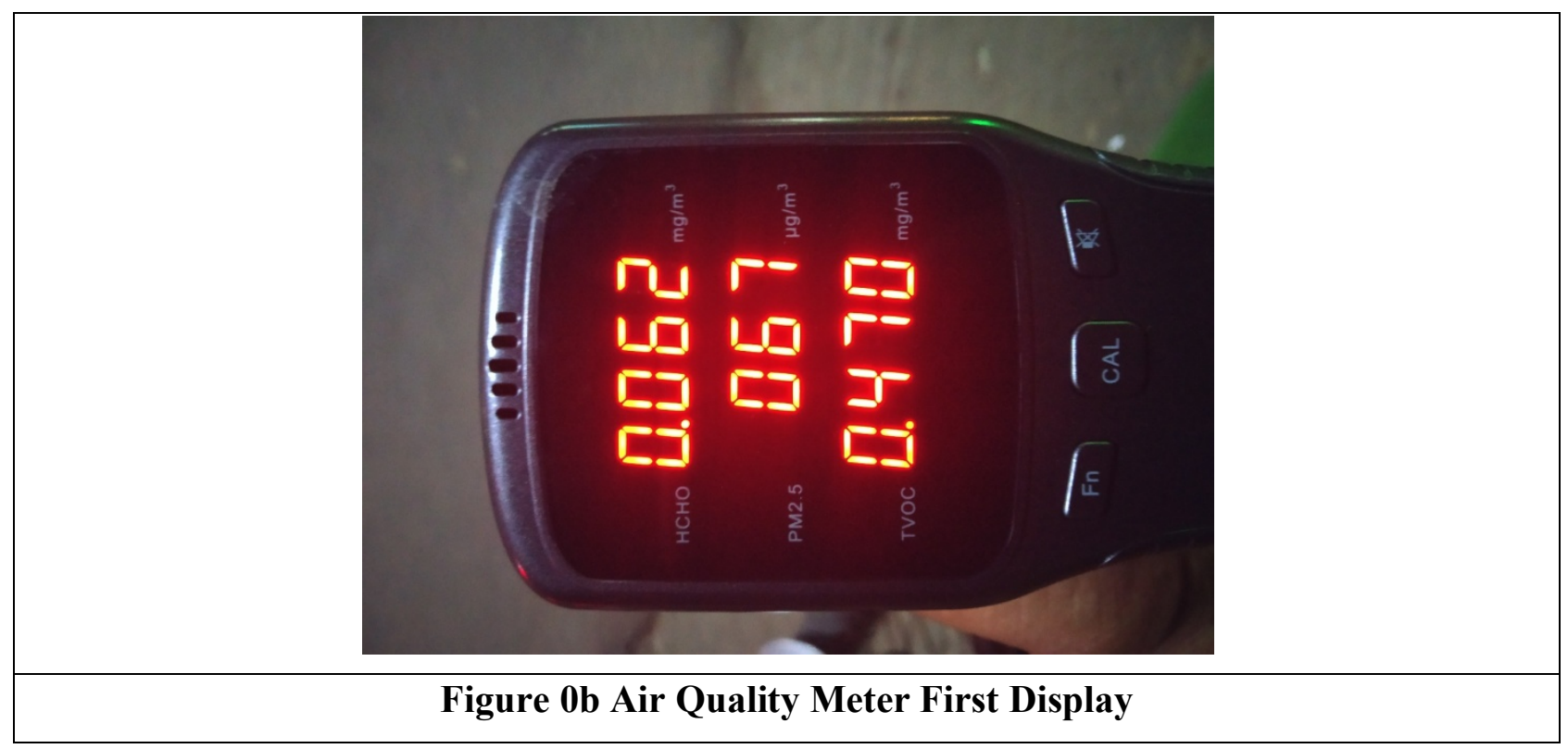

162

Table 2 Pollution Level - Karur Bus Stand (Jan 05, 2019)

\begin{tabular}{|c|c|c|c|c|c|}
\hline Time & $\begin{array}{c}\mathrm{PM}_{1} \\
\mu \mathrm{g} / \mathrm{m}^{3}\end{array}$ & $\begin{array}{l}\mathrm{PM}_{2.5} \\
\mu \mathrm{g} / \mathrm{m}^{3}\end{array}$ & $\begin{array}{c}P M_{10} \\
\mu \mathrm{g} / \mathrm{m}^{3}\end{array}$ & $\begin{array}{l}\mathrm{HCHO} \\
\mathrm{mg} / \mathrm{m}^{3}\end{array}$ & $\begin{array}{l}\text { TVOC } \\
\mathrm{mg} / \mathrm{m}^{3}\end{array}$ \\
\hline $6 \mathrm{AM}-7 \mathrm{AM}$ & 21 & 41 & 32 & 0.003 & 0.001 \\
\hline $7 \mathrm{AM}-8 \mathrm{AM}$ & 28 & 47 & 35 & 0.001 & 0.003 \\
\hline $8 \mathrm{AM}-9 \mathrm{AM}$ & 37 & 53 & 52 & 0.02 & 0.103 \\
\hline $9 \mathrm{AM}-10 \mathrm{AM}$ & 52 & 61 & 71 & 0.031 & 0.221 \\
\hline $10 \mathrm{AM}-11 \mathrm{AM}$ & 60 & 79 & 88 & 0.05 & 0.353 \\
\hline $11 \mathrm{AM}-12 \mathrm{PM}$ & 79 & 101 & 113 & 0.006 & 0.078 \\
\hline $12 \mathrm{PM}-1 \mathrm{PM}$ & 39 & 54 & 58 & 0.003 & 0.031 \\
\hline $1 \mathrm{PM}-2 \mathrm{PM}$ & 41 & 55 & 61 & 0.025 & 0.189 \\
\hline $2 \mathrm{PM}-3 \mathrm{PM}$ & 34 & 45 & 50 & 0.004 & 0.036 \\
\hline $3 \mathrm{PM}-4 \mathrm{PM}$ & 22 & 30 & 33 & 0.014 & 0.143 \\
\hline $4 \mathrm{PM}-5 \mathrm{PM}$ & 78 & 101 & 113 & 0.19 & 0.195 \\
\hline $5 \mathrm{PM}-6 \mathrm{PM}$ & 87 & 122 & 13 & 0.259 & 0.599 \\
\hline $6 \mathrm{PM}-7 \mathrm{PM}$ & 92 & 138 & 27 & 0.221 & 0.762 \\
\hline $7 \mathrm{PM}-8 \mathrm{PM}$ & 66 & 85 & 94 & 0.179 & 0.992 \\
\hline $8 \mathrm{PM}-9 \mathrm{PM}$ & 243 & 321 & 359 & 0.01 & 0.117 \\
\hline $9 \mathrm{PM}-10 \mathrm{PM}$ & 103 & 126 & 147 & 0.014 & 0.092 \\
\hline $10 \mathrm{PM}-11 \mathrm{PM}$ & 66 & 88 & 98 & 0.009 & 0.088 \\
\hline
\end{tabular}

Table 3 Pollution Level - Karur By-Pass Junction (Jan 06, 2019)

\begin{tabular}{|c|c|c|c|c|c|}
\hline Time & $\begin{array}{c}P_{1} \\
\mu \mathrm{g} / \mathbf{m}^{3}\end{array}$ & $\begin{array}{l}P_{2.5} \\
\mu \mathrm{g} / \mathrm{m}^{3}\end{array}$ & $\begin{array}{l}P_{10} \\
\mu g / \mathbf{m}^{3}\end{array}$ & $\begin{array}{l}\mathrm{HCHO} \\
\mathrm{mg} / \mathrm{m}^{3}\end{array}$ & $\begin{array}{l}\text { TVOC } \\
\mathrm{mg} / \mathrm{m}^{3}\end{array}$ \\
\hline $6 \mathrm{AM}-7 \mathrm{AM}$ & 19 & 28 & 21 & 0.004 & 0.002 \\
\hline $7 \mathrm{AM}-8 \mathrm{AM}$ & 23 & 33 & 25 & 0.002 & 0.001 \\
\hline $8 \mathrm{AM}-9 \mathrm{AM}$ & 49 & 52 & 59 & 0.009 & 0.097 \\
\hline $9 \mathrm{AM}-10 \mathrm{AM}$ & 51 & 69 & 77 & 0.177 & 0.186 \\
\hline $10 \mathrm{AM}-11 \mathrm{AM}$ & 64 & 85 & 95 & 0.027 & 0.231 \\
\hline $11 \mathrm{AM}-12 \mathrm{PM}$ & 42 & 56 & 60 & 0.012 & 0.115 \\
\hline
\end{tabular}




\begin{tabular}{|c|c|c|c|c|c|}
\hline $12 \mathrm{PM}-1 \mathrm{PM}$ & 50 & 66 & 75 & 0.003 & 0.041 \\
\hline $1 \mathrm{PM}-2 \mathrm{PM}$ & 28 & 38 & 42 & 0.039 & 0.278 \\
\hline $2 \mathrm{PM}-3 \mathrm{PM}$ & 41 & 57 & 62 & 0.008 & 0.083 \\
\hline $3 \mathrm{PM}-4 \mathrm{PM}$ & 24 & 32 & 35 & 0.01 & 0.1 \\
\hline $4 \mathrm{PM}-5 \mathrm{PM}$ & 18 & 24 & 27 & 0.188 & 0.77 \\
\hline $5 \mathrm{PM}-6 \mathrm{PM}$ & 22 & 30 & 33 & 0.016 & 0.164 \\
\hline $6 \mathrm{PM}-7 \mathrm{PM}$ & 40 & 31 & 28 & 0.023 & 0.205 \\
\hline $7 \mathrm{PM}-8 \mathrm{PM}$ & 41 & 55 & 61 & 0.234 & 0.667 \\
\hline 8 PM-9PM & 54 & 72 & 80 & 0.062 & 0.47 \\
\hline $9 \mathrm{PM}-10 \mathrm{PM}$ & 62 & 68 & 73 & 0.022 & 0.16 \\
\hline $10 \mathrm{PM}-11 \mathrm{PM}$ & 32 & 48 & 55 & 0.011 & 0.091 \\
\hline
\end{tabular}

Table 0 Pollution Level - Vaiyapuri Nagar (Feb 09, 2019)

\begin{tabular}{|c|c|c|c|c|c|}
\hline Time & $\begin{array}{c}\text { PM }_{1} \\
\mu \mathrm{g} / \mathrm{m}^{3}\end{array}$ & $\begin{array}{l}\mathbf{P M}_{2.5} \\
\mu \mathrm{g} / \mathrm{m}^{3}\end{array}$ & $\begin{array}{l}\mathrm{PM}_{10} \\
\mu \mathrm{g} / \mathrm{m}^{3}\end{array}$ & $\begin{array}{l}\mathrm{HCHO} \\
\mathrm{mg} / \mathrm{m}^{3}\end{array}$ & $\begin{array}{l}\text { TVOC } \\
\mathrm{mg} / \mathrm{m}^{3}\end{array}$ \\
\hline $6 \mathrm{AM}-7 \mathrm{AM}$ & 17 & 28 & 19 & 0.001 & 0.001 \\
\hline $7 \mathrm{AM}-8 \mathrm{AM}$ & 28 & 27 & 39 & 0.001 & 0.007 \\
\hline $8 \mathrm{AM}-9 \mathrm{AM}$ & 53 & 71 & 90 & 0.002 & 0.009 \\
\hline $9 \mathrm{AM}-10 \mathrm{AM}$ & 48 & 65 & 72 & 0.009 & 0.11 \\
\hline $10 \mathrm{AM}-11 \mathrm{AM}$ & 42 & 56 & 62 & 0.007 & 0.153 \\
\hline $11 \mathrm{AM}-12 \mathrm{PM}$ & 41 & 57 & 61 & 0.01 & 0.06 \\
\hline $12 \mathrm{PM}-1 \mathrm{PM}$ & 38 & 50 & 57 & 0.006 & 0.063 \\
\hline $1 \mathrm{PM}-2 \mathrm{PM}$ & 34 & 45 & 49 & 0.018 & 0.21 \\
\hline $2 \mathrm{PM}-3 \mathrm{PM}$ & 36 & 48 & 53 & 0.019 & 0.198 \\
\hline $3 \mathrm{PM}-4 \mathrm{PM}$ & 16 & 24 & 26 & 0.015 & 0.174 \\
\hline $4 \mathrm{PM}-5 \mathrm{PM}$ & 19 & 27 & 28 & 0.016 & 0.23 \\
\hline $5 \mathrm{PM}-6 \mathrm{PM}$ & 23 & 30 & 33 & 0.016 & 0.35 \\
\hline $6 \mathrm{PM}-7 \mathrm{PM}$ & 32 & 40 & 43 & 0.021 & 0.43 \\
\hline $7 \mathrm{PM}-8 \mathrm{PM}$ & 38 & 43 & 47 & 0.011 & 0.071 \\
\hline $8 \mathrm{PM}-9 \mathrm{PM}$ & 49 & 54 & 48 & 0.009 & 0.091 \\
\hline $9 \mathrm{PM}-10 \mathrm{PM}$ & 59 & 67 & 77 & 0.027 & 0.207 \\
\hline $10 \mathrm{PM}-11 \mathrm{PM}$ & 37 & 41 & 39 & 0.011 & 0.12 \\
\hline
\end{tabular}

Table 5 Pollution Level - Near EB Office (Feb 10, 2019)

\begin{tabular}{|c|c|c|c|c|c|}
\hline Time & $\begin{array}{c}\mathrm{PM}_{1} \\
\mu \mathrm{g} / \mathrm{m}^{3}\end{array}$ & $\begin{array}{l}\mathbf{P M}_{2.5} \\
\mu \mathrm{g} / \mathrm{m}^{3}\end{array}$ & $\begin{array}{l}\mathbf{P M}_{10} \\
\mu \mathrm{g} / \mathbf{m}^{3}\end{array}$ & $\begin{array}{l}\mathrm{HCHO} \\
\mathrm{mg} / \mathrm{m}^{3}\end{array}$ & $\begin{array}{l}\text { TVOC } \\
\mathrm{mg} / \mathrm{m}^{3}\end{array}$ \\
\hline $6 \mathrm{AM}-7 \mathrm{AM}$ & 21 & 38 & 16 & 0.007 & 0.051 \\
\hline $7 \mathrm{AM}-8 \mathrm{AM}$ & 29 & 41 & 23 & 0.011 & 0.099 \\
\hline 8 AM - 9 AM & 38 & 50 & 53 & 0.024 & 0.171 \\
\hline $9 \mathrm{AM}-10 \mathrm{AM}$ & 41 & 56 & 52 & 0.061 & 0.25 \\
\hline $10 \mathrm{AM}-11 \mathrm{AM}$ & 40 & 53 & 59 & 0.06 & 0.145 \\
\hline $11 \mathrm{AM}-12 \mathrm{PM}$ & 44 & 59 & 64 & 0.03 & 0.114 \\
\hline $12 \mathrm{PM}-1 \mathrm{PM}$ & 47 & 67 & 68 & 0.165 & 0.061 \\
\hline $1 \mathrm{PM}-2 \mathrm{PM}$ & 27 & 36 & 40 & 0.112 & 0.042 \\
\hline $2 \mathrm{PM}-3 \mathrm{PM}$ & 26 & 33 & 37 & 0.081 & 0.031 \\
\hline $3 \mathrm{PM}-4 \mathrm{PM}$ & 26 & 35 & 38 & 0.07 & 0.049 \\
\hline $4 \mathrm{PM}-5 \mathrm{PM}$ & 33 & 37 & 38 & 0.031 & 0.274 \\
\hline $5 \mathrm{PM}-6 \mathrm{PM}$ & 18 & 24 & 27 & 0.23 & 2.96 \\
\hline $6 \mathrm{PM}-7 \mathrm{PM}$ & 27 & 35 & 38 & 0.29 & 1.99 \\
\hline $7 \mathrm{PM}-8 \mathrm{PM}$ & 33 & 37 & 39 & 0.281 & 1.53 \\
\hline $8 \mathrm{PM}-9 \mathrm{PM}$ & 38 & 41 & 48 & 0.221 & 1.79 \\
\hline
\end{tabular}




\begin{tabular}{|c|c|c|c|c|c|}
\hline $9 \mathrm{PM}-10 \mathrm{PM}$ & 45 & 49 & 54 & 0.209 & 1.83 \\
\hline $10 \mathrm{PM}-11 \mathrm{PM}$ & 31 & 33 & 41 & 0.145 & 1.13 \\
\hline
\end{tabular}

\subsection{IMPACT ANALYSIS}

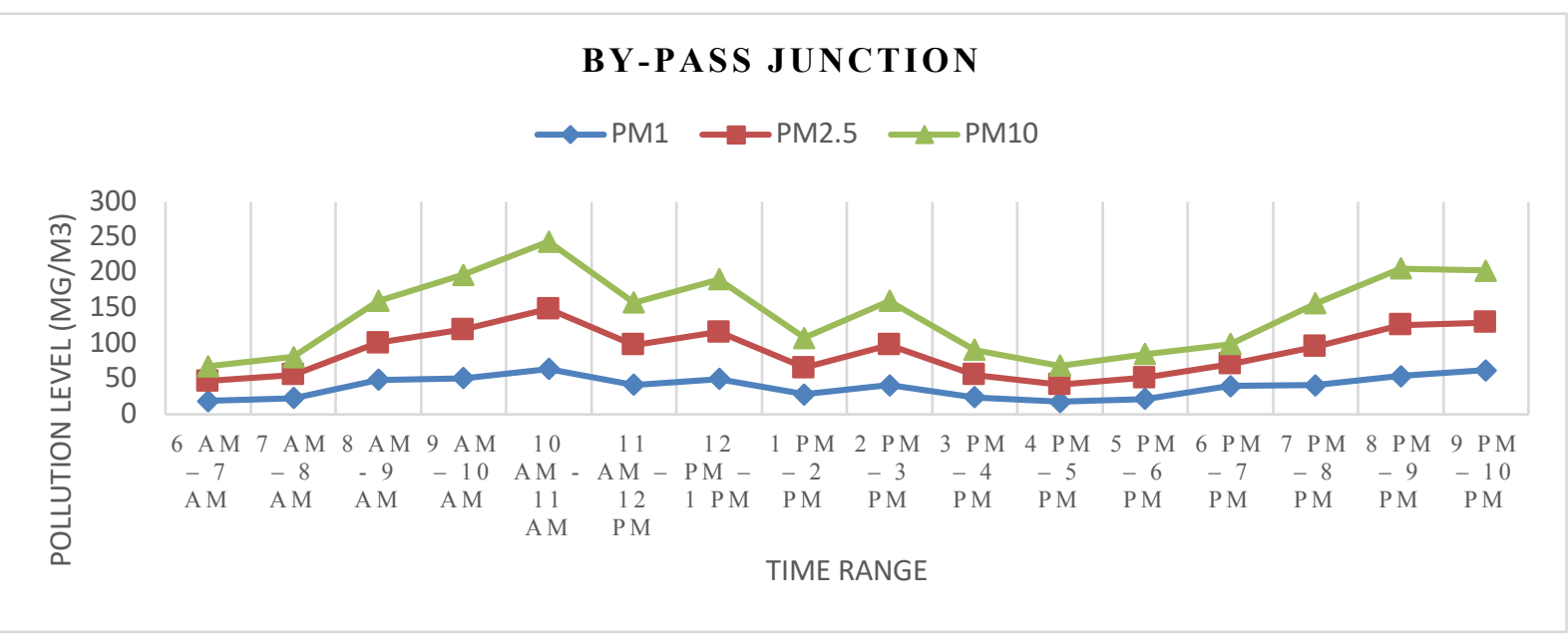

The measured values are clearly showing that the pollution will increase based on the increase in the temperature.

$>$ From morning the temperature starts to increase hence the pollution level is slightly increasing.

$>$ During noon even though the temperature is higher due to the less movement of vehicles, the pollution level is primarily moderate.

$>$ After $5 \mathrm{PM}$, the temperature starts to fall, and the effect of high temperature remains increasing gradually till night. Simultaneously the traffic density is also increasing because of the peak hour, the pollution level is increasing as well.

$>$ The following graphs will show the variations in the pollution level based on the time variation.

$>$ In which the Time variations in the X-axis and pollution level in $\mathrm{Y}$-axis $\left(\mu \mathrm{g} / \mathrm{m}^{3}\right)$.

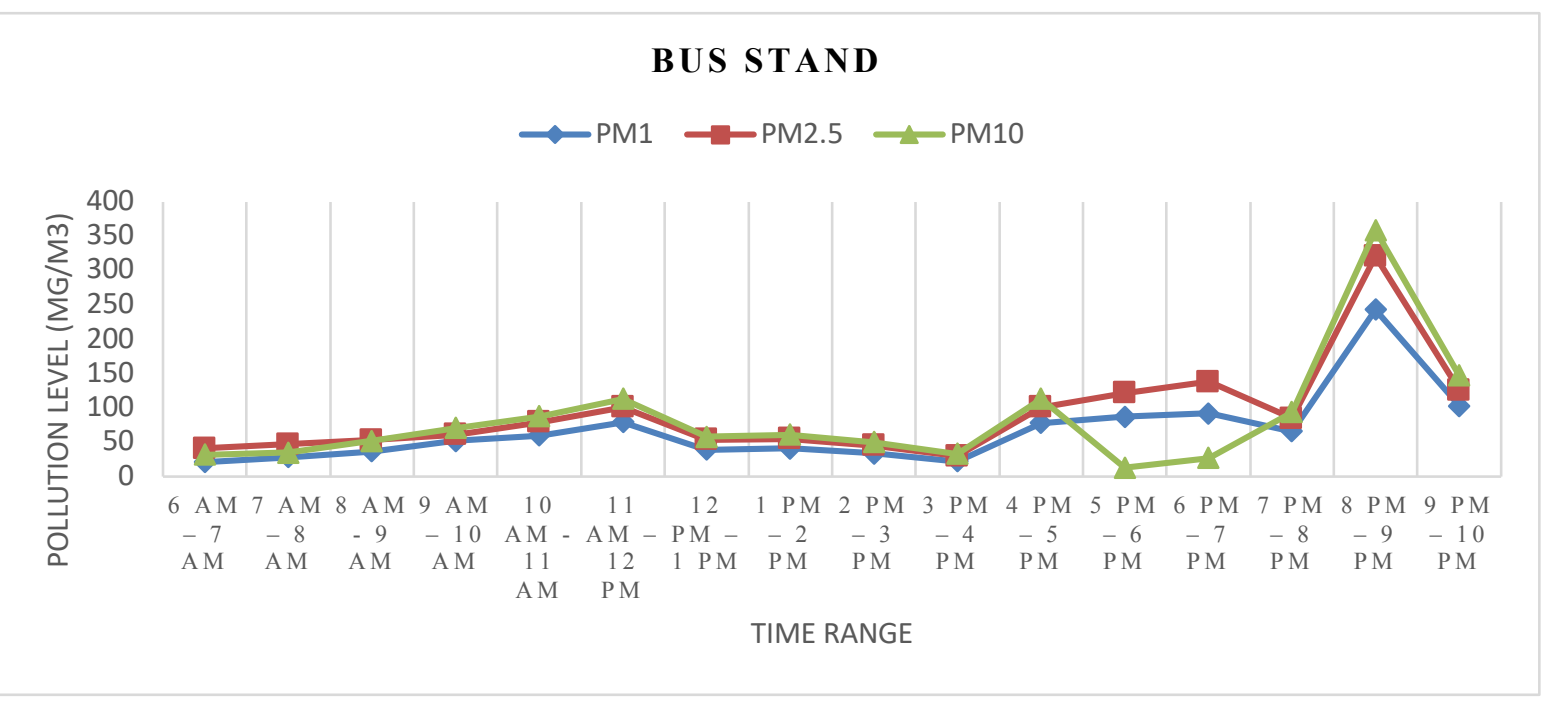

Figure 5 Graph showing pollution level - Karur Bus Stand 


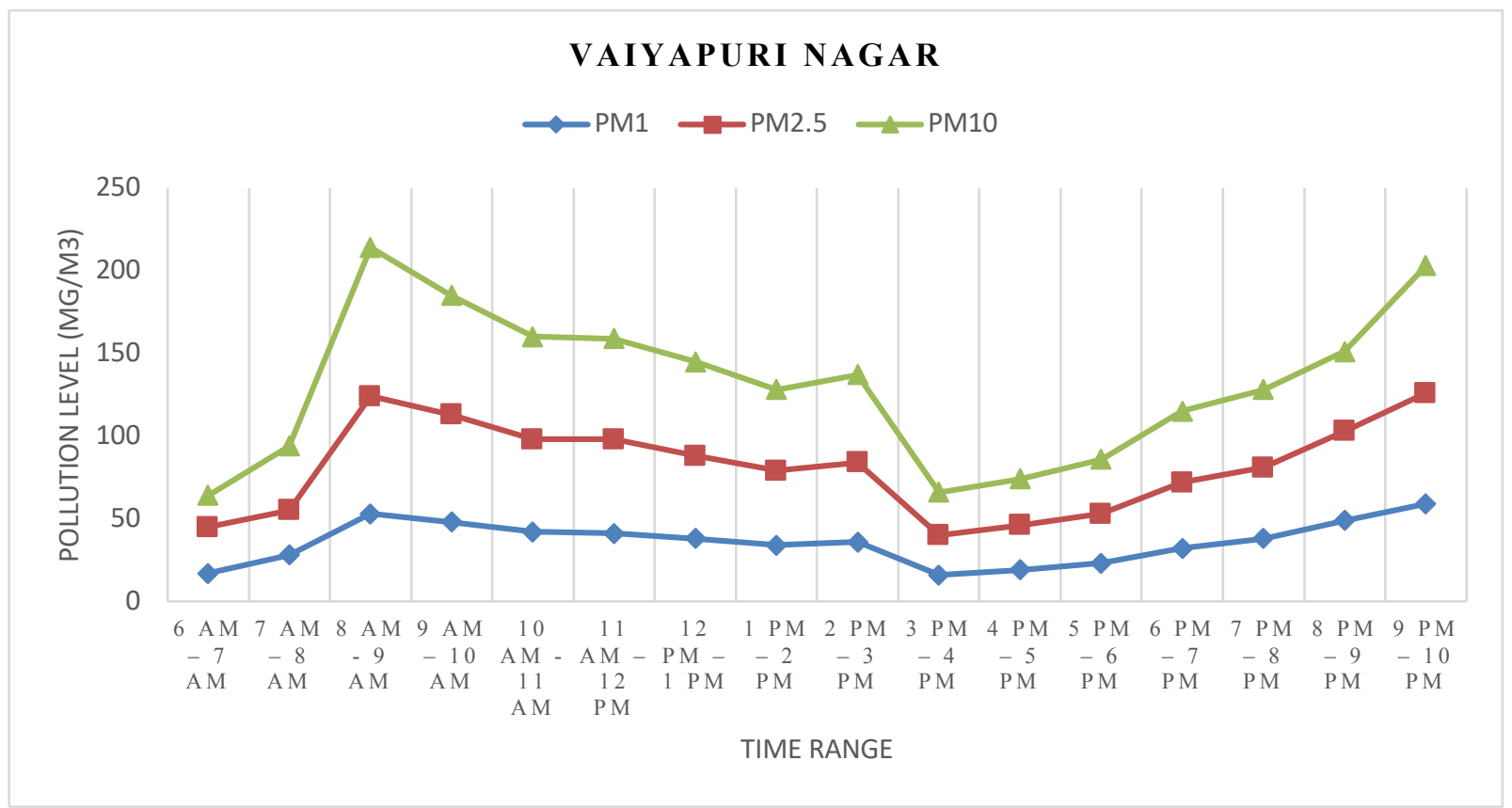

Figure 7 Graph showing pollution level - Vaiyapuri Nagar

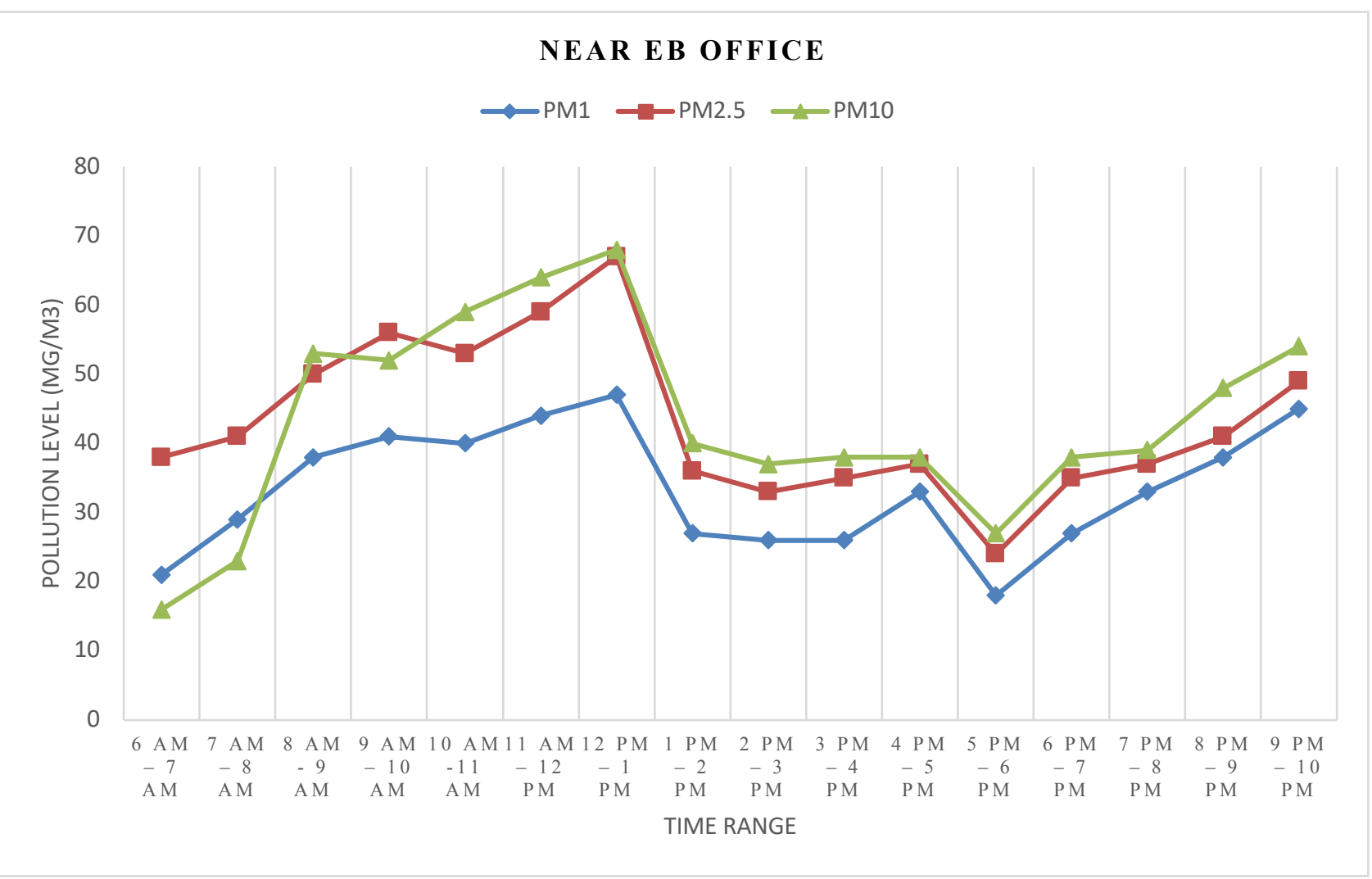




\begin{tabular}{|c|c|c|c|c|c|c|c|}
\hline Time (Min) & $\mathbf{0}$ & $\mathbf{1 5}$ & $\mathbf{3 0}$ & $\mathbf{4 5}$ & $\mathbf{6 0}$ & $\mathbf{7 5}$ & $\mathbf{9 0}$ \\
\hline PM1 $_{\mathbf{1}}\left(\boldsymbol{\mu g} / \mathbf{m}^{\mathbf{3}}\right)$ & 195 & 151 & 109 & 88 & 69 & 59 & 48 \\
\hline $\mathbf{P M}_{2.5}\left(\boldsymbol{\mu g} / \mathbf{m}^{\mathbf{3}}\right)$ & 258 & 207 & 173 & 151 & 98 & 86 & 53 \\
\hline $\mathbf{P M}_{\mathbf{1 0}}\left(\boldsymbol{\mu g} / \mathbf{m}^{\mathbf{3}}\right)$ & 293 & 246 & 201 & 167 & 112 & 95 & 72 \\
\hline HCHO $\left(\mathbf{m g} / \mathbf{m}^{\mathbf{3}}\right)$ & 0.023 & 0.019 & 0.015 & 0.011 & 0.008 & 0.006 & 0.006 \\
\hline TVOC $\left(\mathbf{m g} / \mathbf{m}^{\mathbf{3}}\right)$ & 0.42 & 0.37 & 0.32 & 0.28 & 0.21 & 0.18 & 0.15 \\
\hline
\end{tabular}

\subsection{REDUCTION OF POLLUTION USING HIGH-PERFORMANCE AIR PURIFIER}

After seeing the results of pollution measurement, it clearly shows that the air was highly polluted and purified(Myatt TA et al. 2008). We are experimentally going to run the prepared Air Purifier under various pollution level and Temperature range (Francis $\mathrm{H}$ et al. 2003). The pollution level checked near the outlet for outdoor testing.

The Purifier tested in the following three areas,

* Class Room of VSB Engineering College, Karur.

* Residential Area I in K. Paramathi, Karur.

* Residential Area II in K. Paramathi, Karur.

\subsection{TESTING OF AIR PURIFIER IN CLASSROOM (INDOOR)}

The classroom of the VSB Engineering College located on the first floor of Main Building II and 600m from NH 67. The temperature during testing is slightly pleasant and may in the range of $30^{\circ} \mathrm{C}$ to $33^{\circ} \mathrm{C}$. The pollution level in this place is low to moderate(Gore RB et al. 2003). The dimensions of the classroom are 15Ft.X 20Ft.X 15Ft. The volume maybe about 4500 cubic feet. During the experimentation, all the windows and doors are closed.

The test conducted from 1:30 PM to $3 \mathrm{PM}$ in the range of 15 minutes. The results tabulated from 0 to 90 minutes.

Table 6 Test results of Air Purifier - Class Room (Indoor)

\begin{tabular}{|c|c|c|c|c|c|c|c|}
\hline Time $(\mathbf{M i n})$ & $\mathbf{0}$ & $\mathbf{1 5}$ & $\mathbf{3 0}$ & $\mathbf{4 5}$ & $\mathbf{6 0}$ & $\mathbf{7 5}$ & $\mathbf{9 0}$ \\
\hline $\mathbf{P M}_{\mathbf{1}}\left(\boldsymbol{\mu g} / \mathbf{m}^{\mathbf{3}}\right)$ & 41 & 33 & 31 & 25 & 22 & 18 & 17 \\
\hline $\mathbf{P M}_{\mathbf{2 . 5}}\left(\boldsymbol{\mu g} / \mathbf{m}^{\mathbf{3}}\right)$ & 43 & 38 & 33 & 28 & 25 & 19 & 18 \\
\hline $\mathbf{P M}_{\mathbf{1 0}}\left(\boldsymbol{\mu g} \mathbf{m} \mathbf{m}^{\mathbf{3}}\right)$ & 49 & 39 & 37 & 30 & 23 & 19 & 19 \\
\hline HCHO $\left(\mathbf{m g} / \mathbf{m}^{\mathbf{3}}\right)$ & 0.054 & 0.048 & 0.031 & 0.028 & 0.011 & 0.006 & 0.001 \\
\hline TVOC $\left(\mathbf{m g} / \mathbf{m}^{\mathbf{3}}\right)$ & 0.326 & 0.291 & 0.276 & 0.211 & 0.112 & 0.041 & 0.013 \\
\hline
\end{tabular}

\subsection{TESTING OF AIR PURIFIER IN RESIDENTIAL AREA I (OUTDOOR)}

A residential area ofAnnai Nagar, K. Paramathi village is selected for the first phase of outdoor testing(Yamamoto N et al. 2010). The place is just located $100 \mathrm{~m}$ from $\mathrm{NH} \mathrm{67}$, and the test conducted during the evening. The temperature is low and may in the range of $29^{\circ} \mathrm{C}$ to $32^{\circ} \mathrm{C}$. However, the effect of temperature was not reduced and may impact the pollution level. As we expected the pollution is high in this place.

The test conducted from 7:30 PM to 9:00 PM in the range of 15 minutes.

Table 7 Test results of Air Purifier - Residential Area I (Outdoor)

\subsection{TESTING OF AIR PURIFIER IN RESIDENTIAL AREA II (OUTDOOR)}

A residential area ofK. Paramathi village selected for the first phase of outdoor testing. The place is just located 800 $\mathrm{m}$ from $\mathrm{NH} 67$, and the test conducted during the evening. The temperature is high and may in the range of $34^{\circ} \mathrm{C}$ to $38^{\circ} \mathrm{C}$. However, the natural feel was significant higher than the forecasted temperature, which may impact the pollution level, even though the place having a very low density of traffic. As we expected the pollution is high in this place. 
The test conducted from 2:00 PM to 3:30 PM in the range of 15 minutes.

Table 8 Test results of Air Purifier - Residential Area II (Outdoor)

\begin{tabular}{|c|c|c|c|c|c|c|c|}
\hline Time (Min) & $\mathbf{0}$ & $\mathbf{1 5}$ & $\mathbf{3 0}$ & $\mathbf{4 5}$ & $\mathbf{6 0}$ & $\mathbf{7 5}$ & $\mathbf{9 0}$ \\
\hline PM⿻ $_{\mathbf{1}}\left(\boldsymbol{\mu g} / \mathbf{m}^{\mathbf{3}}\right)$ & 51 & 45 & 38 & 31 & 26 & 22 & 19 \\
\hline $\mathbf{P M}_{2.5}\left(\boldsymbol{\mu g} / \mathbf{m}^{\mathbf{3}}\right)$ & 55 & 47 & 41 & 34 & 27 & 24 & 18 \\
\hline $\mathbf{P M}_{\mathbf{1 0}}\left(\boldsymbol{\mu g} / \mathbf{m}^{\mathbf{3}}\right)$ & 58 & 41 & 32 & 29 & 26 & 21 & 18 \\
\hline HCHO $\left(\mathbf{m g} / \mathbf{m}^{\mathbf{3}}\right)$ & 0.009 & 0.007 & 0.004 & 0.004 & 0.002 & 0.001 & 0.001 \\
\hline TVOC $\left(\mathbf{m g} / \mathbf{m}^{\mathbf{3}}\right)$ & 0.019 & 0.011 & 0.008 & 0.006 & 0.005 & 0.005 & 0.004 \\
\hline
\end{tabular}

218

219

220

221

222

223

224

225

226

227

228

229

230

231

232

233

234

235

236

\section{RESULT AND DISCUSSIONS}

\subsection{REMOVAL EFFICIENCY OF AIR PURIFIER}

The efficiency is the ratio of pollution level before and after applying the Air Purifier.

$$
\text { Removal Efficiency }=\frac{\text { Initial Pollution Level }- \text { Final Pollution Level }}{\text { Initial Pollution Level }} \times 100
$$

\subsection{CALCULATION OF EFFICIENCY OF AIR PURIFIER - INDOOR}

$\mathrm{PM}_{1}$ Removal Efficiency $=\frac{41-17}{41} X 100=58.53 \%$

$\mathrm{PM}_{2.5}$ Removal Efficiency $=\frac{43-18}{43} X 100=58.13 \%$

$\mathrm{PM}_{10}$ Removal Efficiency $=\frac{49-19}{49} X 100=61.22 \%$

\subsection{CALCULATION OF EFFICIENCY OF AIR PURIFIER - OUTDOOR I}

$\mathrm{PM}_{1}$ Removal Efficiency $=\frac{195-48}{195} X 100=75.38 \%$

$\mathrm{PM}_{2.5}$ Removal Efficiency $=\frac{258-53}{258} X 100=79.46 \%$

$\mathrm{PM}_{10}$ Removal Efficiency $=\frac{293-72}{293} X 100=75.43 \%$

\subsection{CALCULATION OF EFFICIENCY OF AIR PURIFIER - OUTDOOR II}

$\mathrm{PM}_{1}$ Removal Efficiency $=\frac{51-19}{51} X 100=62.75 \%$

$\mathrm{PM}_{2.5}$ Removal Efficiency $=\frac{55-18}{55} X 100=67.27 \%$

$\mathrm{PM}_{10}$ Removal Efficiency $=\frac{58-18}{58} X 100=68.97 \%$ 
5.5 RESULT AND DISCUSSIONS

238 The test results are analysed and discussed with the following three graphs and the calculated removal efficiencies.

\section{CLASS ROOM - INDOOR}

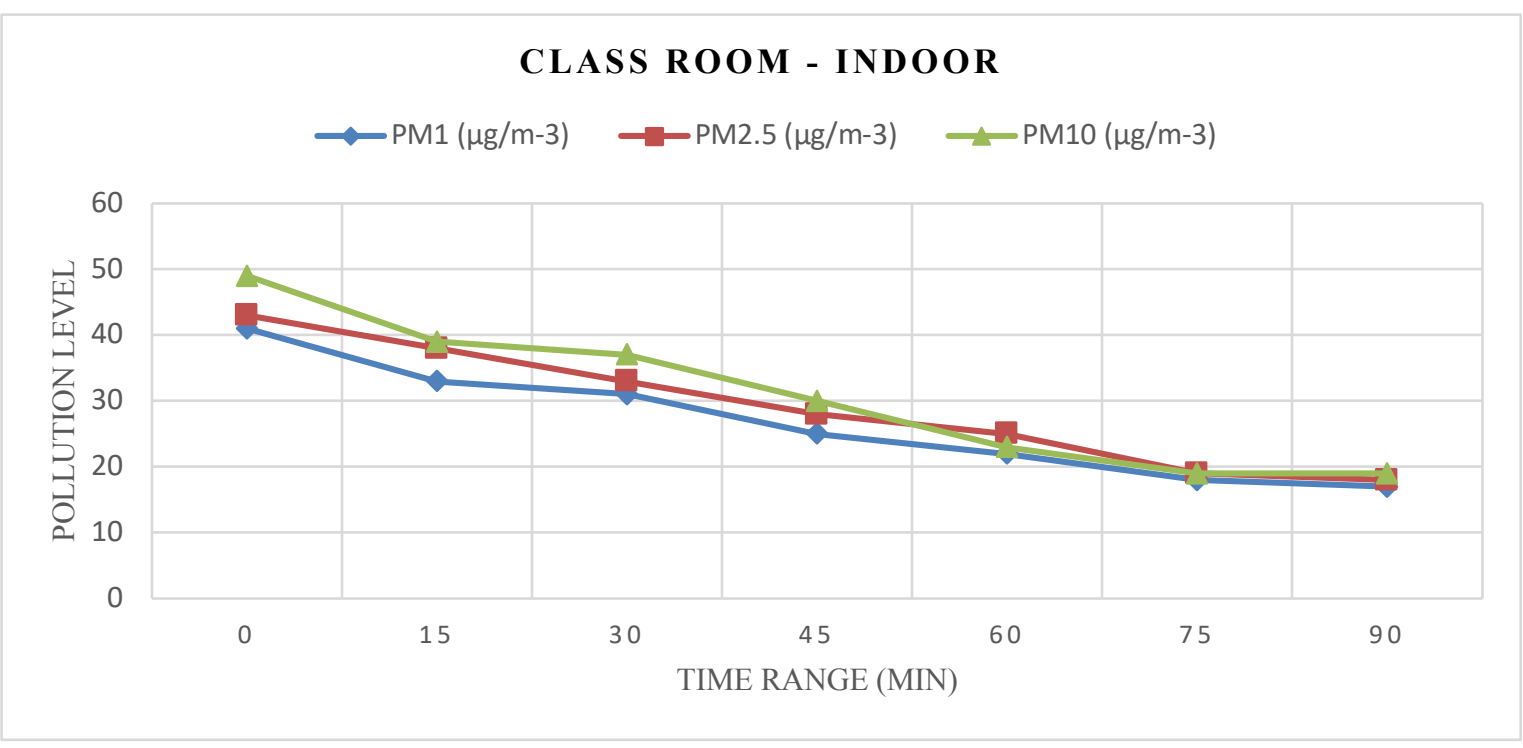

* This graph (figure 5.1) clearly shows that the Air Purifier has a removal efficiency of more than $58 \%$ for removing all the three SPM when the pollution level is low in range.

* The air purifier is operated for 90 minutes continuously.

* In which the $\mathrm{PM}_{10}$ removal is high as more than $61 \%$.

\subsection{RESIDENTIAL AREA I (OUTDOOR)}

* Figure 5.2 showing the graph of the test result of Air Purifier tested in residential area 1 with a high level of pollution.

* It shows the overall removal efficiency of more than $75 \%$ after continuous running for 90 minutes.

* It removed the $\mathrm{PM}_{2.5}$ as high as more than $79 \%$. 


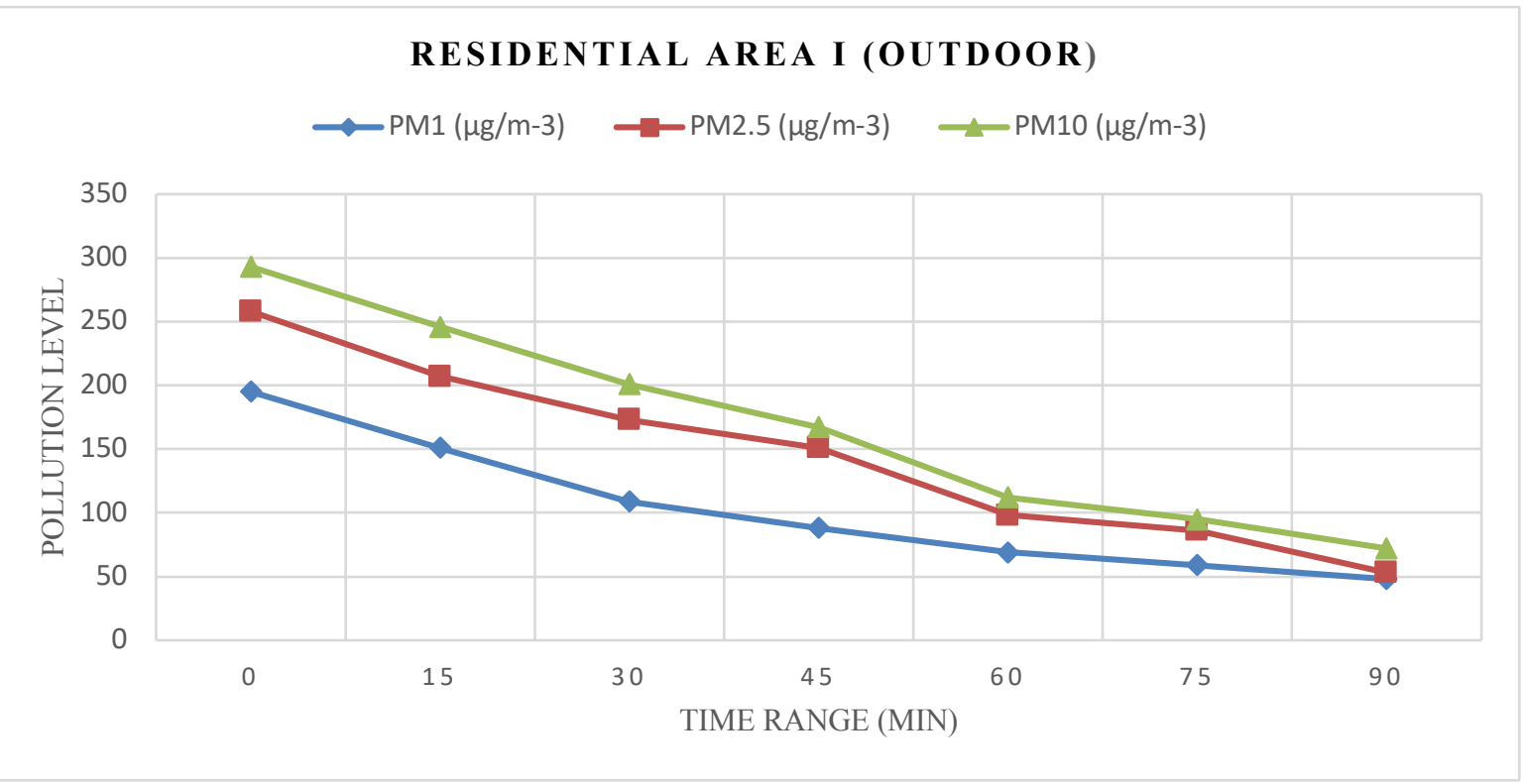

Figure 10 Graph - Result analysis of Residential area I (Outdoor)

* It shows the overall removal efficiencies of more than $62 \%$ after continuous running for 90 minutes.

* It removed the $\mathrm{PM}_{10}$ as high as more than $68 \%$.

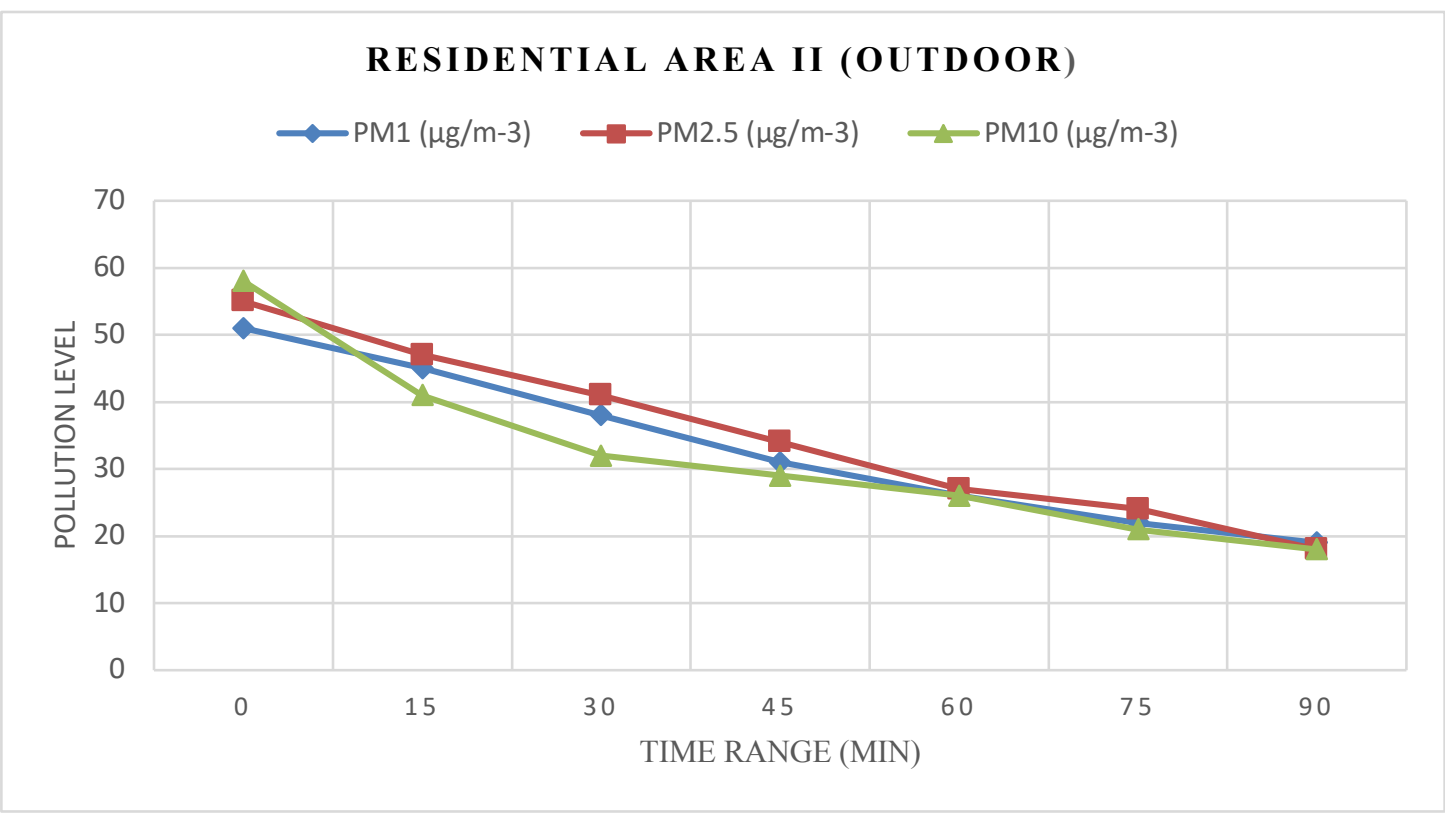


5.8 OVERALL ANALYSIS OF REMOVAL EFFICIENCY

REMOVAL EFFICIENCY UP TO 90 MINUTES

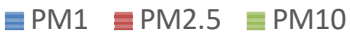

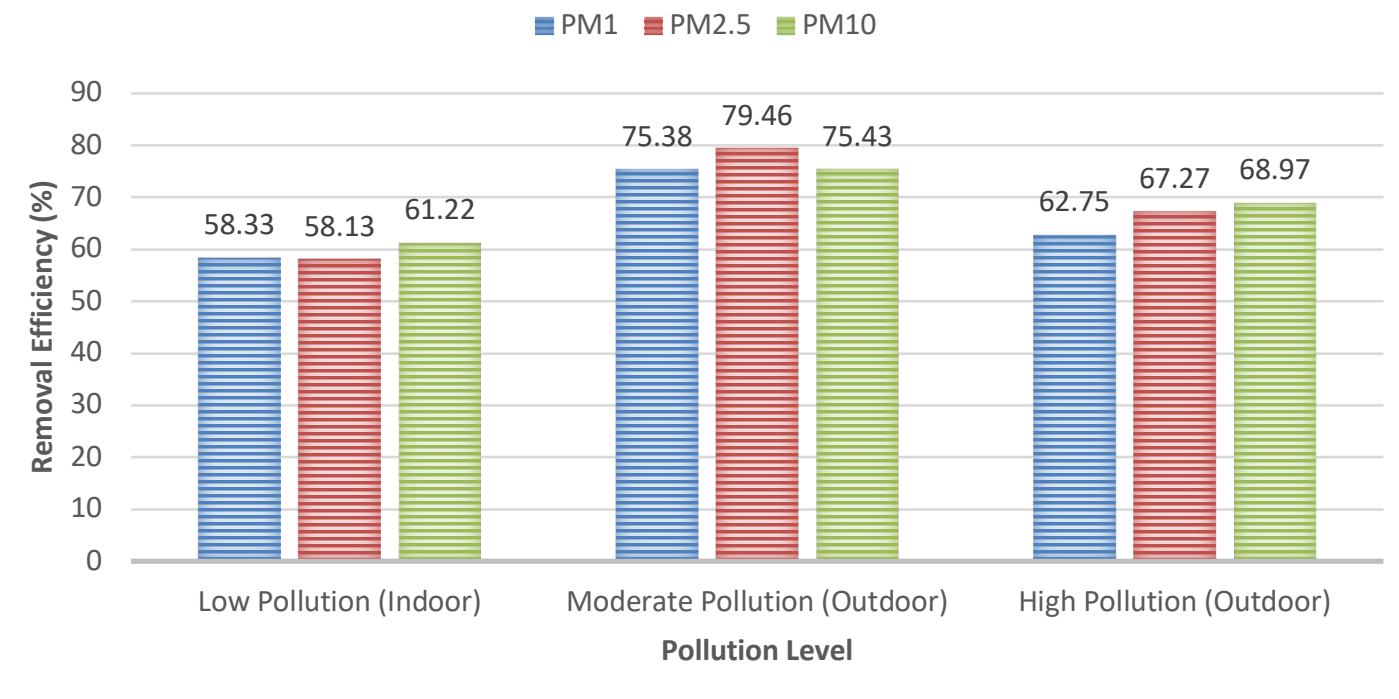

Figure 12 Removal efficiency result upto 90 minutes

Figure 5.4 shows that, the High-Performance air purifier successfully removes almost $60 \%$ of the SPM after a continuous run of 90 minutes.

The pollution level and the temperature variations also having a vital role in the removal efficiency.

\section{CONCLUSIONS}

After elaborate study, we can conclude this project with two parts. They are,

- Solution for Air Pollution

- Future Implementation

\subsection{SOLUTION FOR AIR POLLUTION}

- After completing of the tests on various pollution levels and temperature, this model can reduce the pollution level to the WHO permitted leveland even less than those standards.

- World Health Organisation provided the standards for the $\mathrm{PM}_{2.5}$ and $\mathrm{PM}_{10}$ as below:

$\mathrm{PM}_{2.5}: 10 \mu \mathrm{g} / \mathrm{m}^{3}$ - annual mean \& $25 \mu \mathrm{g} / \mathrm{m}^{3}-24$ hour mean

$\mathrm{PM}_{10}: 20 \mu \mathrm{g} / \mathrm{m}^{3}$ - annual mean \& $50 \mu \mathrm{g} / \mathrm{m}^{3}-24$ hour mean.

- But this purifier with hair and Vetiver as filter media reduces almost $60 \%$ of the pollution causing SPM from the air within 90 minutes. Air temperature also can reduce about 40 to 50c.

- It observed that whenever pollution levels are high-performance also high, which is nearly $90 \%$. Hence this purifier is much suitable for highly polluted areas.

- If large membranes provided, then the efficiency will be increased up to $90 \%$.

- It is possible to provide large membranes since both filter media are bio-degradable. So, it does not create any impacts on the environment in the name of environmental development.

- It will reduce the air pollution and also reduce the severe diseases like cancer and asthma. 
286 As iteffectively reducesthe air pollution in an manner without having any side effects to the environment as well as 287 humanely, it can be implemented in public places and residential places.

288 By using quiet motors, we can adopt this purifier in any kind of environment.

289 Air pollution due to the burning of fossil fuels will become higher due to the increase in the rate of vehicles sale in 290 India. It will lead to an increase in $\mathrm{CO}_{2}$ concentration in the atmosphere.

291 Hence, this is the one way to reduce the SPM released from the burning of fossil fuels and many sources.

292 Now, India has lost many cities which, aretheir living suitability due to the increase in air pollution.

293 Example: Delhi, Mumbai and some cities of Chennai.

294 We recommend this purifier in an enlarged manner to reduce the air pollution and bring back the cities to their 295 previous status without air pollution.

296

297

298

299

300

301

302

303

304

305

306

307

308

309 
312 We want to express and convey our thankfulness to the management who provided the lab facility to conduct experiments as well as our principal for the good opportunity to do the work on this wonderful topic of (Development of High-Performance Air Purifier using Human Hair and Vetiver (Chrysopogan Zizanioides) as Filter Media).

316 Ethical approval-This content is fully prepared by our own.

Consent to participate-We are consenting to participate.

Consent to publish-We are consenting to publish.

Author's Contribution -

Anand Kumar Varma S. conducted the research work for the full experimental recordings and completion of the full work with the entire correction.

Suvalakshmi A. works for the entire manuscript preparation.

Manjula.K.R making model, revised the entire manuscript and verified the data .

Funding-No funding source for this content.

Competing interests-Completed by each author.

Availability of data and materials-

We measured the pollution level from different outdoor places .

$$
\begin{array}{ll}
\text { * } & \text { Bypass Junction } \\
\text { Vaiyapuri Nagar } \\
\text { * Near EB Office } \\
\text { Karur Bus Stand }
\end{array}
$$

We measured the pollution level from different indoor places

* The classroom of the VSB Engineering College located on the first floor of Main Building.

* A residential area ofAnnai Nagar, K. Paramathi village is selected for the first phase of outdoor testing.

* A residential area ofK. Paramathi village selected for the first phase of outdoor testing.

\section{Durham, North Carolina "Fundamentals of Air Pollution- Fourth Edition".}

Daniel A. Vallero Civil and Environmental Engineering Department, Pratt School of Engineering, Duke University,

345 Dr. A.B. Akolkar "National Air Quality Index" Control Of Urban Pollution Series Cups/82/2014-15. AQI 95; 346 Satisfactory Responsible Pollutant $\mathrm{PM}_{10}$.

347 "Formaldehyde", WHO Regional Office for Europe, Copenhagen, Denmark, 2001. 
Pollution Prevention and Abatement Handbook-World Bank Group“Airborne Particulate Matter: Pollution $350 \quad$ Prevention and Control" July 2008.

Shri J. S. Kamyotra,Dr. D. D. Basu "National Ambient Air Quality Status \& Trends in India-2010".National Ambient Air Quality Monitoring NAAQMS/ 35 /2011-2012.

United States Environmental Protection Agency “Air Quality Index - A Guide to Air Quality and Your Health”. 354 February 2014 EPA-456/F-14-002.

355 "WHO Air quality guidelines for particulate matter, ozone, nitrogen dioxide and sulfur dioxide", Global update, 3562005.

\subsection{JOURNALS}

A.B. Ozturk,el al(2011)“Does Nasal Hair (Vibrissae) Density Affect the Risk of Developing Asthma in Patients with Seasonal Rhinitis?"

Adams, R. P., el al. (1998) DNA fingerprinting reveals clonal nature of Vetiveria zizanioides (L.) Nash, Gramineae and sources of potential new germplasm. Molecular Ecology, 7(7), 813-818. DOI: 10.1046/j.1365362 294x.1998.00394.x

Aditya Roy el al. (2018) A review of general and modern methods of air purificationFebruary 2018Journal of 364 Thermal Engineering 5(2):22-28DOI:10.18186/thermal.529054

Akarsh Verma, V.K. el al. (2016) "Human Hair: A Biodegradable Composite Fiber - A Review"International Journal of Waste Resources 6(2) DOI: 10.4172/2252-5211.1000206

Angus Shiue, . elal (2019)"Verification of air cleaner on-site modeling for $\mathrm{PM}_{2.5}$ and TVOC purification in a full-

Annie Melinda Paz-Alberto,.elal(2013)“Phytoremediation: A Green Technology to Remove Environmental Pollutants"

Ashton Lim Suelee el al. (2017)Phytoremediation Potential of Vetiver Grass (Vetiveria zizanioides) for Treatment 372 of Metal-Contaminated Water

373 Balasanka.D r, . el al(2013)“Traditional and Medical Uses of Vetiver”

Batterman S, (2005) Godwin C, Jia C. Long duration tests of room airfilters in cigarette smokers' homes. Environ Sci Technol. 2005;39(18):7260-8

Bernstein JA et al. (2005) A pilot study to investigate the effects ofcombined dehumidification and HEPA filtration on dew point andairborne mold spore counts in day care centers. Indoor Air.2005;15(6):402-7.

381 Danh, L. T.,. el al.(2009). Vetiver grass, Vetiveria zizanioides: a choice plant for phytoremediation of heavy metals

Chomchalow, N. (2003). The role of vetiver in controlling water quantity and treating water quality: an overview with special reference to Thailand. AU J T, 6(3), 145-116.

Darajeh, Nel al.., (2014). Phytoremediation potential of vetiver system technology for improving the quality of palm

oil mill effluent. Advances in Materials Science and Engineering, 1-10. Article ID 683579, DOI: $10.1155 / 2014 / 683579$ 
EmilyCheek el al. (2021), Portable air purification: Review of impacts on indoor air quality and healthScience of The Total EnvironmentVolume 766, 20 April 2021, 142585https://doi.org/10.1016/j.scitotenv.2020.142585

Fisk WJ et al. (2002) Performance and costs of particle air filtrationtechnologies. Indoor Air. 2002;12(4):223-34.

Fortoul, T.I. el al. (2011) “Air Pollution and Its Effects in the Respiratory System”

Francis $\mathrm{H}$ et al. (2003) Clinical effects of air filters in homes of asthmaticadults sensitized and exposed to pet allergens. Clin Exp Allergy.2003;33(1):101-5.

Gore RB et al. (2003) Air filtration units in homes with cats: can theyreduce personal exposure to cat allergen? Clin Exp Allergy.2003;33(6):765-9.

Green $\mathrm{R}$ et al (1999). The effect of air filtration on airborne dog allergen.Allergy. 1999;54(5):484-8

Hanssen(2004) SO. HVAC - the importance of clean intake section and dryair filter in cold climate. Indoor Air. 2004;14 Suppl 7:195-201.

Hacker DW, et al. (2005) Sparrow EM. Use of air-cleaning devices to create airborne particle-free spaces intended to alleviate allergic rhinitis and asthma during sleep. Indoor Air. 2005;15(6):420-31.

James L. Sublett(2011)Effectiveness of Air Filters and Air Cleanersin Allergic Respiratory Diseases: A Review of the RecentLiterature Curr Allergy Asthma Rep (2011) 11:395-402DOI 10.1007/s11882-011-0208-5.

Johnson L., et al. (2009) Low-cost interventions improve indoor airquality and children's health. Allergy Asthma Proc. 2009;30(4):377-85. This was the first clinical study of asthma using environmental control practice that includes WHF.

Julie F. HartHindawi el al. (2011) Evaluating the Effectiveness of a Commercial Portable Air Purifier in Homes with Wood Burning Stoves: A Preliminary Study Publishing Corporation Journal of Environmental and Public Health Volume 2011, Article ID 324809, 7 pages doi:10.1155/2011/324809

M. Sharma,. el al(2003) "Design of a website for dissemination of air quality index in India"

Macintosh D.L. et al(2008). Whole house particle removal and cleanair delivery rates for in-duct and portable ventilation systems. JAir Waste Manage Assoc. 2008;58(11):1474-82. This is anintroduction of a new standard that allows comparison of variousfiltration systems in a multiroom test house.

Mickovski, S. el al. (2005) Uprooting of vetiver uprooting resistance of vetiver grass (Vetiveria zizanioides). Plant and Soil, 278(1/2), 33-41. DOI: 10.1007/s11104-005-2379-0

Morris RJ et al. (2006) A novel air filtration delivery system improves seasonal allergic rhinitis. Allergy Asthma Proc. 2006;27(1):63-7.

Myatt TA et al. (2008) Control of asthma triggers in indoor air with aircleaners: a modeling analysis. Environ Health. 2008;7:43.

P. Thilagaraj, . el al(2014) “A Study on AIR Pollution and Its Impact on Human Health in Chennai City”

Pedroletti C et al. (2009) Clinical effects of purified air administered to the breathing zone in allergic asthma: a double-blind randomized cross-over trial. Respir Med. 2009;103(9):1313-9.

Review on air purifier Gowri Rajapandian el al. (2019) * ,. Publication history: Received on 14 March 2019; revised on 29 March 2019; accepted on 03 April 2019 Article DOI: https://doi.org/10.30574/gscbps.2019.7.1.0038 
427 Rojas-Sandoval J, (2020). Chrysopogon zizanioides (vetiver). Invasive Species Compendium. Wallingford, UK:

428 CABI. DOI:10.1079/ISC.18528934.20203483484

429 Stillerman A. et al. (2010) Efficacy of a novel air filtration pillow foravoidance of perennial allergens in 430 symptomatic adults. AnnAllergy Asthma Immunol. 2010;104(5):440-9. This was a welldesigned study using 431 validated clinical outcomes.

Sublett J.L., et al. (2010) Air filters and air cleaners: rostrum by theAmerican Academy of Allergy, Asthma \& Immunology IndoorAllergen Committee. J Allergy Clin Immunol. 2010;125(1):32-8. This is a comprehensive review of residential air filtration, varioustypes of filtration available, characterization of airborne particulates,and standards for rating both HVAC and room aircleaners. It also provides recommendations related to futureresearch.

437

438

Sulser C et al. (2009) Can the use of HEPA cleaners in homes ofasthmatic children and adolescents sensitized to cat and dogallergens decrease bronchial hyperresponsiveness and allergencontents in solid dust? Int Arch Allergy Immunol. 2009;148(1):23-30

441 V. P. Singh and Pawan Kumar (2017) "Potential of Vetiver Plant (Chrysopogan Zizanioides) in Phytoremediation 442 Technique"

443 Van Boven F.E. el al. (2020)Effectiveness of the Air Purification Strategies for the Treatment of Allergic Asthma: A 444 Meta-Analysis Int Arch Allergy Immunol 2020;181:395-402https://doi.org/10.1159/000506284

445 Vannan Kandi Vijayan el al. (2015) "Enhancing indoor air quality -The air filter advantage”Lung India. 2015 Sep446 Oct; 32(5): 473-479.DOI: 10.4103/0970-2113.164174

447 Yamamoto $\mathrm{N}$ et al. (2010) Residential air exchange rates in three majorUS metropolitan areas: results from the 448 Relationship AmongIndoor, Outdoor, and Personal Air Study 1999-2001. Indoor Air.2010;20(1):85-90.

449

450

Yun Han Wang el al. (2015), Research Progress of Air Purifier Principles and Material TechnologiesAdvanced

451 Materials Research (Volumes 1092-1093)DOI:https://doi.org/10.4028/www.scientific.net/AMR.1092-1093.1025

452 March 2015

453 Zhe Wang,el al. (2016) A Novel Hierarchical Structured Poly(lactic acid)/Titania Fibrous Membrane with Excellent 454 Antibacterial Activity and Air Filtration Performance Volume 2016|Article 455 ID 6272983 | https://doi.org/10.1155/2016/6272983 